\title{
Data Envelopment Analysis in Financial services: A Citations Network Analysis of Banks, Insurance Companies and Money Market Funds
}

\author{
Sepideh Kaffash ${ }^{\mathrm{ab}}$ and Marianna Marra ${ }^{\mathrm{c}, 1}$
}

a Department of Accounting and Finance, University of Massachusetts Boston, 100 Morrissey Blvd., Boston, MA 02125, United States.

b Department of Management Science E Information Systems, University of Massachusetts Boston, 100 Morrissey Blvd., Boston, MA 02125, United States.

' Management Science and Entrepreneurship Department, Essex Business School, Essex University, UK.

\begin{abstract}
Development and application of the Data Envelopment Analysis (DEA) method, have been the subject of numerous reviews. In this paper, we consider the papers that apply DEA methods specifically to financial services, or which use financial services data to experiment with a newly introduced DEA model. We examine 620 papers published in journals indexed in the Web of Science database, from 1985 to April 2016. We analyse the sample applying citations network analysis.

This paper investigates the DEA method and its applications in financial services. We analyse the diffusion of DEA in three sub-samples: (1) banking groups, (2) money market funds, and (3) insurance groups by identifying the main paths, that is, the main flows of the ideas underlying each area of research. This allows us to highlight the main approaches, models and efficiency types used in each research areas. No unique methodological preference emerges within these areas. Innovations in the DEA methodologies (network models, slacks based models, directional distance models and Nash bargaining game) clearly dominate recent research.

For each subsample, we describe the geographical distribution of these studies, and provide some basic statistics related to the most active journals and scholars.
\end{abstract}

Keywords: Data Envelopment Analysis, financial services, literature survey, citation analysis, main path analysis.

\footnotetext{
${ }^{1}$ Corresponding author Tel: +44(0)1702 328406; Email: $\underline{\text { mmarra@essex.ac.uk }}$
} 


\section{Introduction}

Data Envelopment Analysis (DEA) is a nonlinear programming model introduced by Charnes, Cooper and Rhodes in 1978, based on the work of Farrell (1957). DEA provides a new definition of efficiency, applicable to evaluation of the activities of not-for-profit entities participating in public programmes, measured using DEA. Numerous researchers have studied DEA, both theoretically and practically. The theoretical works have produced developments based on CCR (Charnes et al. 1978) and BCC (Banker et al. 1984), and propose very sophisticated models such as dynamic DEA, network DEA and stochastic DEA, comprising categorical variables - discretionary and nondiscretionary, negative and undesirable variables, and many more. In practice, DEA has been applied in a wide range of applications such as banking, agriculture, transportation, health care, energy sectors, education and many other sectors.

There are several interesting reviews (both general and specific) related to our study. The group of more general reviews includes the first review of DEA, conducted one by Seiford and Thrall (1990), which examines its early-stage developments. Seiford (1996) provides a DEA bibliography covering the period 1978-1996, while Grosskopf (1996) provides a short, selective survey of statistical inferences and nonparametric efficiencies. Gattoufi et al. (2004) report a list of DEA related studies conducted over the period 1951-2001. Cooper et al. (2007) discuss past DEA models and measures, and potential developments. Emrouznejad et al. (2008) provide a bibliography of references related to DEA covering the first 30 years of DEA development. Cook and Seiford (2009) describe DEA developments since the late 1970s. Liu et al. (2013a, b) conduct two citations-based DEA literature analyses covering 1978 to 2010, and Lampe and Hilgers (2015) provide a comprehensive joint analysis of DEA and Stochastic Frontier Analysis (SFA) publications. The most recent reviews are Liu et al. (2016) and Liu et al. (2015). Liu and colleagues present a citations-based literature review of bootstrapping and two-stage analysis, undesirable factors, 
cross-efficiency and ranking, network DEA, dynamic DEA and Slack Based Models (SBM) used in DEA, over the period 2000-2014.

The group of more specific reviews includes surveys of DEA applications to specific fields. Zhou et al. (2008) review the use of DEA in the fields of energy and the environment. Hollingsworth et al. (1999) examine work on the application of DEA to hospitals and the wider general health care context. Some works investigate the implications of frontier efficiency measurements (both parametric and non-parametric) in various fields. For instance, Hollingsworth (2003) presents the methods used in analyses and practical applications of measurement techniques (DEA and SFA). Oum et al. (1999) and Gonzalez and Tujillo (2009) review efficiency measurement studies in respectively rail transport and ports. Worthington (2004) provides a comprehensive review of the implications of frontier efficiency measurements applied to health care in 2004.

The DEA model has proven successful in banking and much of the theoretical work on DEA uses the banking industry as an example to illustrate the numerical or experimental results of new techniques.

Berger et al. (1993) reviews studies of efficiency in financial institutions and possible improvements. Berger and Humphrey (1997) review 130 studies on the application of frontier efficiency to financial institutions in 21 countries. Thanassoulis (1999) discusses application of DEA in the banking industry. Fethi and Pasiouras (2010) provide a survey of over 196 studies of operational research and artificial intelligence techniques used to evaluate banks' performance. The most recently published survey on the efficiency and performance of financial institutions is by Paradi and Zhu (2013), which reviews DEA applications in 80 bank branches. These specific surveys do not adopt quantitative methods, such as citations network analysis, to analyse a large sample of papers. Also, existing reviews refer to a narrow stratum of the financial services sector. We complement the citations network analyses with a qualitative investigation of the most 
relevant papers identified. We highlight the different models and potential applications of DEA in three wide strata of the financial sector - banking, insurance and money market funds. Our analysis covers a long-time period (1985-2016) and provides an overview of the most recent applications and methodological advancements in DEA in financial services. Using data from ISI Web of Science (WoS) academic database of financial institutions, we contribute to research on DEA efficiency along several dimensions.

First, we examine a large set of financial institutions. Following Berger and Humphrey's (1997) survey on the efficiency of financial institutions, there have been numerous studies of financial institution efficiency, including analyses of insurance companies, money market fund providers and brokerage firms. However, the practicality of adopting of DEA to evaluate the efficiency of complex financial institutions warrants some further investigation necessary. Second, since Berger et al. (1993), most reviews focus only on the banking or only on the insurance industry. This makes a comprehensive survey of DEA applications in financial services timely and valuable. Third, Liu et al.'s (2013) review focuses on DEA applications and ranks DEA-application in the banking field. The banking, finance and insurance sectors constitute around $12.5 \%$ of all DEA applicationembedded papers in their study, which is higher than for other fields. Thus, a review that focuses only on DEA application in the financial service sector should be useful.

To deal with the numerous works on DEA published since 1978, we adopt a network-based approach. We analyse the use of DEA in financial institutions by investigating the main networks of collaboration among researchers active in this sector and provide a snapshot of the main flows of ideas characterizing studies of DEA in financial institutions.

\section{Data and methods}

The study of citations to documents has a long tradition. Since the work of Garfield et al. (1964), the study of citations to scientific publications has received increasing attention from network 
analysts, and the network analysis literature includes a growing number of contributions on identification of the so called main path, that is, the main flow of ideas underlying the field of analysis (Necmi Kemal Avkiran and Alpert 2015; Nerur et al. 2008; Whitley and Galliers 2007); technological developments and trajectories in various scientific fields (Barberá-Tomás et al. 2011; Bekkers and Martinelli 2012; Bhupatiraju et al. 2012; Breschi and Lissoni 2003; Epicoco 2013; Fontana et al. 2009; Martinelli 2012; Mina et al. 2007); and emerging knowledge trends within disciplines (Ding et al. 2013; Emrouznejad and Marra 2014; Fan et al. 2014; Lampe and Hilgers 2014; J. S. Liu et al. 2013; Rotolo et al. 2013). Network analysis assumes that, in a citations network (see Figure 1), document B cites document A, in other words, B relies on A to some extent. Thus, citations can be considered a proxy for knowledge flows. Note that the arrows in Figure 1 indicate the citing direction, present to past. The direction of knowledge flows from past to present if a paper published in the past affects subsequent papers. Lucio-Arias and Leydesdorff (2008) point out that: 'This reflects the diffusion of knowledge claims from an original document to documents published thereafter'. In a citations network the startpoint (initial unit) $s$ is a vertex with zero indegree, that is, no arc ends in that vertex, and the endpoint (target unit) $t$ is a vertex with zero outdegree, that is no arc starts in that vertex. In Figure 1, vertices J, I, C are startpoints, while A is an endpoint. The traversal weight of an arc or a vertex is the proportion of all paths between the startpoint and the endpoint that contain this arc or vertex. 


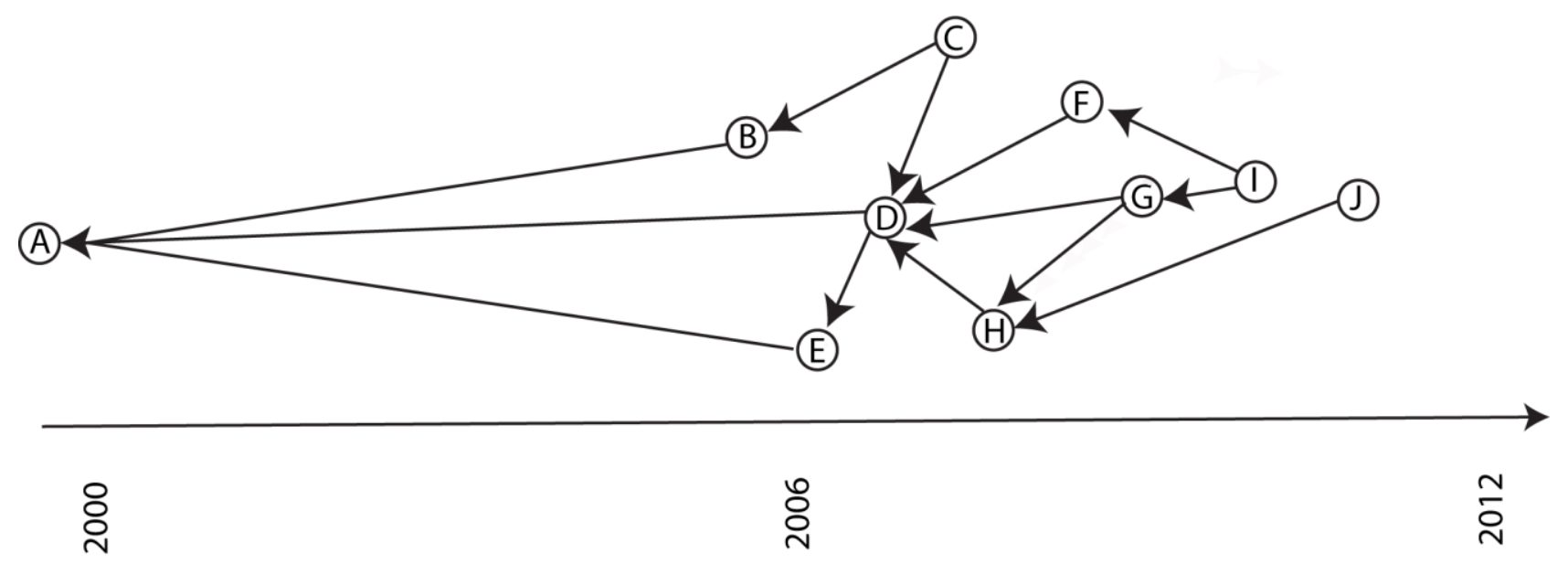

Figure 1. Example of a citations network

Our methodology draws on Hummon and Doreain (1989) and Batagelj (2003). The former proposed an innovation in citations analysis consisting of an approach in which the connective threads running through the network are preserved, and the focus is on the network links rather than the network nodes. Hummon and Doreain's approach to the analysis of connectivity is to focus on sequences of links and nodes or search paths. They propose two algorithms - Search Path Link Count (SPLC) and Search Path Node Pair (SPNP) - which represent a simple way of measuring the importance of a link. SPLC is a simple way of measuring the importance of a link and implies specification of the following concepts. SPLC consists of how many times one arc lies on all possible search paths between all startpoint nodes and endpoint nodes. It is based on counting the number of times a link is traversed by all possible search paths. In Figure 1 the citation arc DA obtains a SPLC value of 3 . There are three possible search paths $(\mathrm{J} \rightarrow \mathrm{A} ; \mathrm{I} \rightarrow \mathrm{A}$; $C \rightarrow A)$. Arc 'DA' lies on these three.

SPNP accounts for all connected node pairs along the search paths, and assigns to each arc the product of the number of its upstream and downstream vertices, thus, an arc in the middle will receive a higher value. The logic underlying SPNP is that citation arcs responsible for connecting higher numbers of nodes contain the most significant knowledge flows in the citations network. In 
Figure 1 the value of SPNP of arc 'DE' is the result of the product of 8 upstream vertices $(\mathrm{D}, \mathrm{B}, \mathrm{C}$, $H, F, G, I, J)$ to 2 downstream vertices $(A, E),(8 \times 2=16)$.

Batagelj's (2003) elaboration of the search path count (SPC) algorithm is considered the best development of Hummon and Doreain's algorithms originally applied to a small citations network which reconstructs the main path in the network of citations between scientific papers leading to the discovery of DNA. Batagelj (2003) also suggests applying the Critical Path Method (CPM) to the network. CPM comes from operational research and can be used to detect the main path in a citations network. CPM determines the s-t path with the maximal value of the sum of weights of the arcs in the path and provides a visual display of broader longitudinal connectivity than the SPC output (Kejžar et al. 2010). Thus, the CPM algorithm is expected to capture the foundations of the field of analysis under investigation, in our case DEA and financial services. Data are analysed using Pajek (Nooy et al. 2005) and HisCite (Garfield 2009) software².

The data are taken from the WoS database, which is a recognized, comprehensive, academic database covering over 10,000 high impact journals and over 120,000 proceedings of international conference, and is a valuable resource for scholars dealing with quantitative and citation-based studies. Data were retrieved using two groups of keywords combined using the search operators 'AND' and 'OR' within the WoS database. The first group was aimed at identifying the field of DEA. We searched for 'DEA', 'Data Envelopment Analysis', 'Malmquist index/indices', 'Total factor productivity', 'non-parametric efficiency' and 'nonparametric efficiency', and 'meta-frontier' and 'metafrontier'. We also searched for another group of terms, aimed at identifying papers dealing only with the area of financial service. We categorized the financial services sector according to four groups for which we used relevant keywords. The banking industry keywords

\footnotetext{
${ }^{2}$ Both software are freely available http://interest.science.thomsonreuters.com/forms/HistCite/ , http://mrvar.fdv.uni-lj.si/pajek/
} 
are: 'banking', 'banks', 'financial institutions', 'micro-finance institutions', 'credit unions', 'financial holding companies (FHC)', 'banking holding companies (BHC)', 'loan and deposit companies', 'financial innovation systems', and 'mortgage loan companies'. Only $10 \%$ of the papers in this group were related to keywords other than bank and banking. The keywords for money market funds are 'investment funds', 'mutual fund', 'hedge funds', 'Real Estate Investment Trust (REITs)','private equity funds', and 'commodity index/indices'. The keywords for insurance industry are: 'insurance firms', 'pension funds', 'Takaful firm', 'compensation company' and 'property liability insurance'. We identified the main path within each thematic group using the CPM algorithm.

The advantage of a network based approach survey over the previous literature review approaches is that it identifies papers that play a vital role in the development of field using citations data. It presents how knowledge in a specific filed has been disseminated. Main path traces the development path of knowledge.

We manually retrieved some papers that were included in previous reviews, but were not identified by our search in WoS. We scrutinized each paper to ensure its relation to DEA and financial institutions, resulting in a final sample of 620 works published between 1985 and April 2016. Based on identification using keywords, banking group is the largest group with 514 papers. Insurance group includes 59 papers and money market funds has the smallest number of papers at 47. This study focuses only on papers that apply non-parametric frontier studies, specifically DEA, in financial services. We consider both methodology-oriented papers, which employ empirical examples in the financial services sector, and application-oriented papers, but exclude purely DEA methodology-oriented papers (for instance: Banker et al, 1984; Cooper et al., 2007). The yearly distribution of papers is depicted in Figure 2, which shows a peak in 2010 corresponding to 65 published papers. The lower value in 2016 is because data collection covered only the first four 
months of 2016 when only 11 papers had been published. The highest number of papers was published in the European Journal of Operational Research (62) followed by Journal of Banking and Finance (48) and Omega (34) (Table 1). Tables 1 presents the top 20 ranked journals based on their Total Local Citation Score (TLCS), which is the number of times the journal's papers included in this collection were cited by other papers in the collection. We also show the Total Global Citation Score (TGCS), which refers to how many times the journal's papers were cited in the entire WoS database. In our case the two scores allow a better understanding of the importance of the journal within DEA and financial services, and also general interest in DEA and financial services per se. Within our sample, Sherman H.D. is the most important author, according to his TLCS (155), with 5 publications. He is followed by Paradi J.C. with TLCS equals 135, Gold F. with TLCS equals 103 and Lovell C.A.K. with TLCS equals 101. 


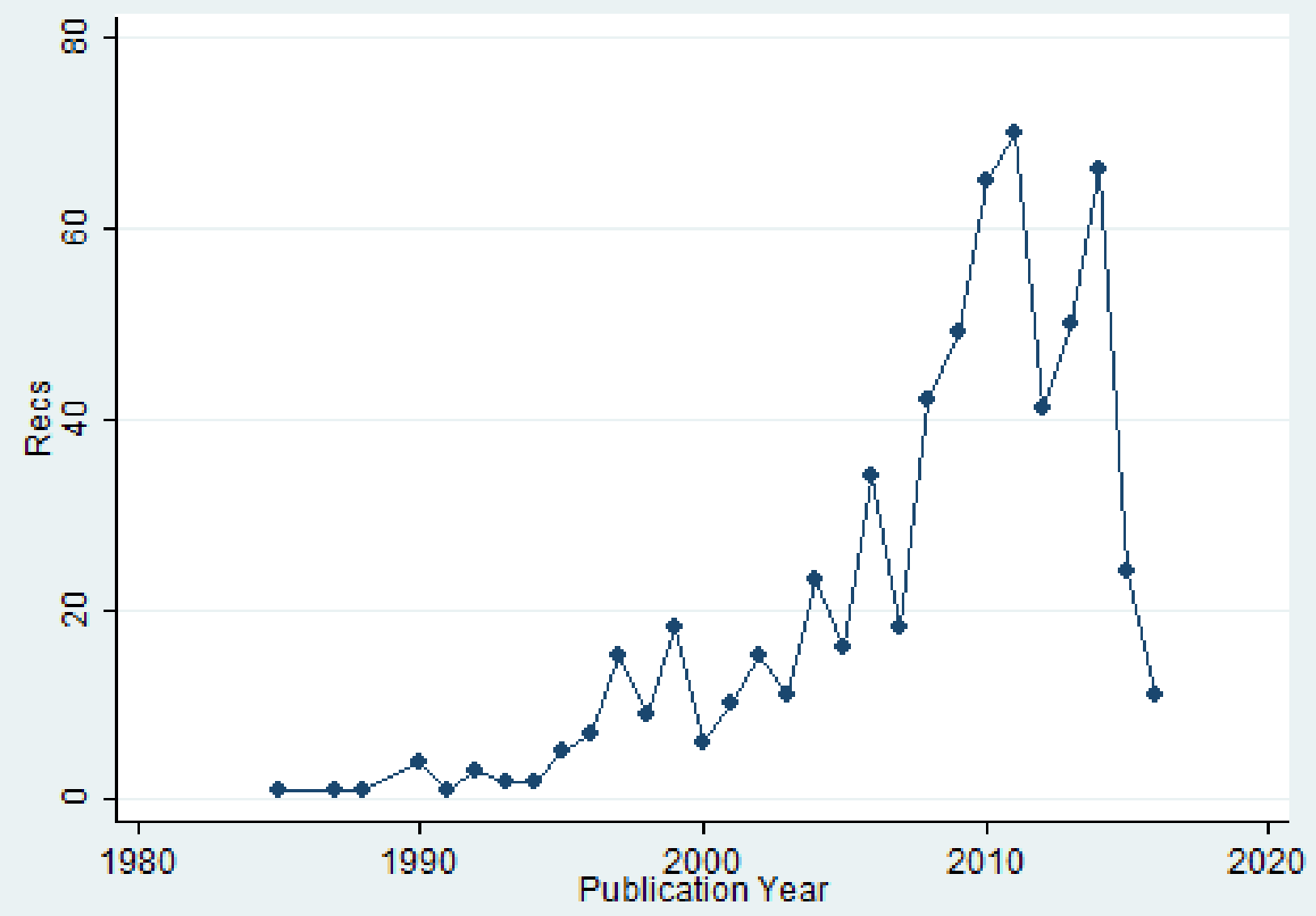

Figure 2. Distribution of papers per year

Table 1. Top 20 journals

\begin{tabular}{|l|l|l|l|l|}
\hline & Journal & No of Papers & TLCS & TGCS \\
\hline 1 & Journal of Banking \& Finance & 48 & 703 & 1483 \\
\hline 2 & European Journal of Operational Research & 62 & 609 & 1643 \\
\hline 3 & Omega - International Journal of Management Science & 34 & 206 & 616 \\
\hline 4 & Applied Economics & 18 & 152 & 300 \\
\hline 5 & Journal of Operational Research Society & 18 & 145 & 378 \\
\hline 6 & Interfaces & 6 & 111 & 199 \\
\hline 7 & Journal of Productivity Analysis & 21 & 352 \\
\hline 8 & Management Science & 2 & 87 & 258 \\
\hline 9 & Journal of Money Credit and Banking & 5 & 69 & 160 \\
\hline 10 & Expert Systems with Applications & 28 & 62 & 220 \\
\hline 11 & China Economic Review & 4 & 58 & 130 \\
\hline 12 & Economic Modelling & 13 & 56 & 74 \\
\hline 13 & Engineering Costs and Production Economics & 1 & 43 & 50 \\
\hline 14 & Journal of Econometrics & 2 & 36 & 52 \\
\hline 15 & Geneva Papers on Risk and Insurance - Issues and Practice & 8 & 32 & 291 \\
\hline 16 & Journal of Business Research & 3 & 31 & 36 \\
\hline 17 & Service Industries Journal & 13 & 30 & 82 \\
\hline 18 & Journal of Financial Services Research & 2 & 29 & 93 \\
\hline 19 & Economics Letters & 3 & 28 & 76 \\
\hline 20 & Annals of Operations Research & 9 & 24 & 76 \\
\hline
\end{tabular}




\section{Geographical Distribution}

In this section, in order to study the wide application of DEA in financial services, we explore the papers in each sub-sample based on four groups - single country studies, two-country studies, economic or geographical region studies, and global studies.

Table 2 illustrates the geographical distribution of banking group papers.

Table 2. Geographical distribution of banking group

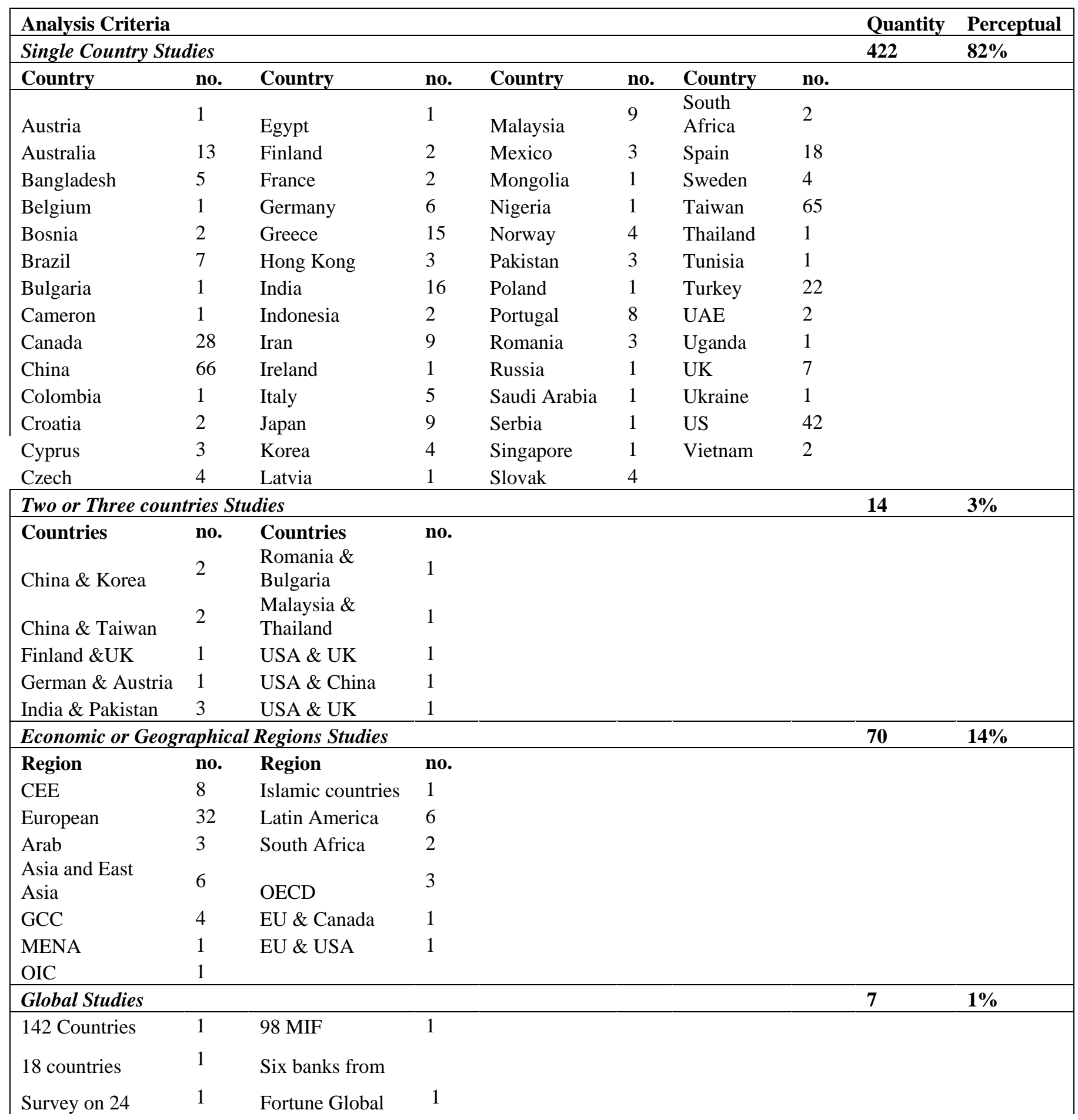




\begin{tabular}{|llll|l|} 
countries & & 500 & & \\
7 countries & 1 & $\begin{array}{l}\text { Survey } 196 \\
\text { studies }\end{array}$ & 1 & $\mathbf{5 1 3}$ \\
72 countries & 1 & & & \\
\hline Total* & & &
\end{tabular}

*Not applicable for one study

CEE Central and Eastern European countries comprising Albania, Bulgaria, Croatia, Czech Republic, Hungary, Poland, Romania, the Slovak Republic, Slovenia, and the three Baltic States: Estonia, Latvia and Lithuania, GCC Golf Corporation Council Countries including Saudi Arabia, Kuwait, the United Arab Emirates, Qatar, Bahrain, and Oman, MENA Middle East and North Africa, BRIC Brazil, Russia, India and China, OECD Organisation for Economic Cooperation and Development, including 34 countries, which includes 21 of the 28 European Union members, OIC Organization of Islamic Conference countries

Table 2 shows that although 55 countries feature in various single-country studies, a disproportionately large number of studies is focused on just a few countries. For instance, the single-country studies show that the three most frequent countries (US, Taiwan and China) account for $41 \%$ of all the studies conducted, with the remaining 52 countries cumulatively accounting for just 59\%. This might point indirectly to the fact that it is in these countries that DEA is most often employed in the banking sector.

Meanwhile, the study covering the largest number of countries is Hauner (2008), which studies the impact of credit to government on banking sector efficiency for 142 countries. We observe also that DEA has been applied extensively in the banking industry globally - evidenced by the fact that 142 individual countries are covered in these studies.

Table 3. Geographical distribution of Money market funds

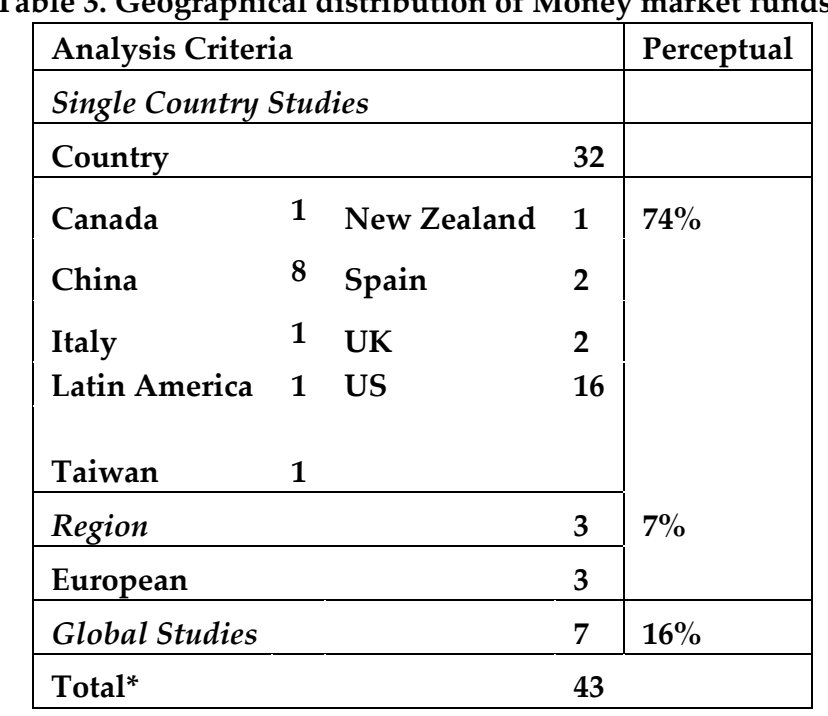

* Not applicable for 4 studies 
Table 3 shows the geographical distribution of money market group papers.

Table 3 also presents a skewed ratio, with 55\% of the papers distributed between just China and the US for the single-country studies. A quarter of all papers, globally, is focussed on US money market funds, which is to be expected since it is an old and well-established market. However, there are only two papers on application of DEA in the UK, another well-developed, but apparently understudied market. 
Table 4. Geographical distribution of Insurance industry

\begin{tabular}{|c|c|c|c|c|}
\hline \multicolumn{2}{|l|}{ Analysis Criteria } & \multicolumn{2}{|c|}{ Analysis Criteria } & \multirow[t]{2}{*}{ Perceptual } \\
\hline Single Country Studies & & Single Country & & \\
\hline Country & & \multicolumn{2}{|c|}{49} & $84 \%$ \\
\hline Angola & 1 & Jordan & 1 & \\
\hline Australia & 1 & Malaysia & 1 & \\
\hline Brazil & 2 & Mozambique & 1 & \\
\hline Canada & 2 & New Zealand & 1 & \\
\hline China & 8 & Portugal & 1 & \\
\hline Croatia & 1 & Serbia & 1 & \\
\hline Czech & 1 & Spain & 4 & \\
\hline Germany & 3 & Taiwan & 6 & \\
\hline Greece & 2 & Thailand & 1 & \\
\hline Iran & 2 & USA & 9 & \\
\hline Two countries Studies & & & 3 & $5 \%$ \\
\hline \multicolumn{4}{|l|}{$\begin{array}{l}\text { China \& Taiwan } \\
\text { Slovenia \& Croatia } \\
\text { Czech \& Slovenia }\end{array}$} & \\
\hline Economic or Geographic & & & 6 & $10 \%$ \\
\hline \multicolumn{4}{|l|}{ Region } & \\
\hline $\begin{array}{l}\text { BRIC } \\
\text { European }\end{array}$ & 1 & $\begin{array}{l}\text { Islamic } \\
\text { Asia, Africa an } \\
\text { Latin America }\end{array}$ & 2 & \\
\hline Global Studies & & & 1 & $1 \%$ \\
\hline 36 Countries & 1 & & 1 & \\
\hline Total & & & 59 & \\
\hline
\end{tabular}

Table 4 presents the geographical distribution of insurance group papers. In line with the trend observed in the Tables 2 and 3, again the US, Taiwan and China have the largest number of papers on application of DEA in the insurance industry. Note also that in this industry, DEA application has been studied in a multi-country context, for example, including the BRIC, Islamic and EU countries.

\section{Main Path}

In this section, we describe the main trajectories of DEA developments in financial services based on two individual main paths: banking group and money market fund group. The nodes are 
papers and the arrows show the direction of the knowledge flows. Each of the papers in the figures is indicated by first author name and date of publication. For example, the paper by Sherman and Gold (1985) is indicated as 'Sherman1985'.

\subsection{Banking main path}

Figure 3 depicts the main path for the banking group, which includes 514 papers, 33 of which are located on the main path. 


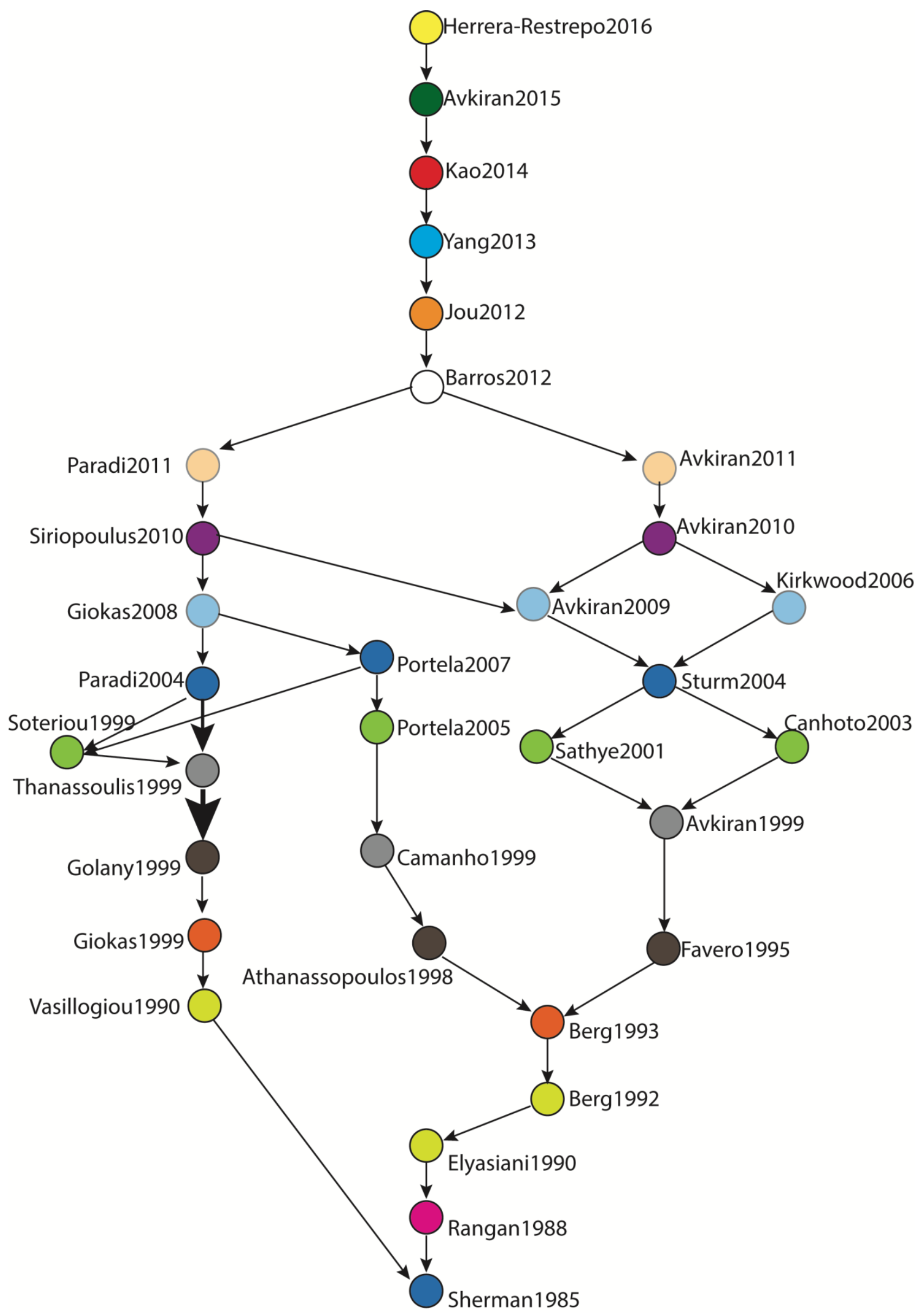

Figure 3. Banking main path 
The first paper on the main path, which is the first published paper on the application of DEA in the banking sector is Sherman1985 Sherman and Gold (1985). It evaluates the operating efficiency of a set of 14 branches of a US savings bank. Two main streams originate from Sherman1985. While the right stream focuses mostly on DEA banking papers at country level, the left stream includes mainly DEA banking papers at bank branch level.

The left stream, Vassiloglou1990 (Vassiloglou and Giokas 1990), presents a systematic application of DEA to assess the relative efficiency of the branches of the Commercial Bank of Greece. Giokas1991 (Giokas 1991), compares the DEA efficiency of 17 branches of the Commercial Bank of Greece in 1988, based on the results of a log-linear model. The findings show that DEA takes account of the structure branch inputs compared to other estimation models. Golany1999 (Golany and Storbeck 1999) develops a number of innovative application tools, including budgeting and target setting models, by applying multi-period DEA to study the efficiency of the branches of a large US bank. The line between this paper and the following paper, Thanassoulis1999 (Thanassoulis 1999) is thicker, which shows a stronger impact on the development of the flow of ideas. Thanassoulis1999 conducts a branch level survey of efficiency in two large banks in Britain and Finland. Two nodes originate from Thanassoulis1999. The first node Paradi2004 (Paradi and Schaffnit 2004), which is the line with the stronger link, focuses on assessing the efficiency of the commercial branches of a large Canadian bank, by introducing the branch's non-discretionary environmental factors and producing Gap maps and target tables for each branch. The second node, Soteriou1999 (Soteriou and Zenios 1999) develops three DEA models - an operational efficiency model, a service quality efficiency model and a profitability efficiency model - to evaluate the performance of the branches of a commercial bank in Cyprus. Their results indicate superior insights when the operations combined with the quality of the services provided and the bank's profitability are analysed simultaneously rather than separately. 
Giokas2008 (Giokas 2008) assesses the efficiency of the branches of a Greek bank from three different dimensions - management of the branch's economic performance, meeting demands for transactions from customers, and generating profits.

The left stream includes two papers. The first, Siriopoulos2010 (Siriopoulos and Tziogkidis 2010), studies the efficiency of 11 Greek banks employing a financial analysis and credit approach, over the period 1995-2003. The authors propose a Change Management Efficiency (CME) index to measure the efficiency of management through a process of change while presenting aggregate figures for the banks' branch development and performance. The second paper, Paradi2011 (Paradi et al. 2011), develops a two-stage DEA analysis approach applying a modified SBM model to aggregate the efficiency scores obtained from the first stage, and generates a composite performance index for each unit for the national branch network of a Canadian bank.

The next paper, where the left and right streams merge, which is Barros2012 (Barros et al. 2012), analyses the technical efficiency of Japanese banks in 2000-2007 using an innovative methodological model based on the Russell directional distance function which considers desirable and undesirable outputs.

The right stream, follows a paper by Rangan et al. (1988) (Rangan1988), which applies a nonparametric frontier approach to measure the technical efficiency of 215 US banks, while Elyasiani1990 (Elyasiani and Mehdian 1990) defines the rate of technological change as the rate of growth of total factor productivity, employing a non-parametric technique for a sample of 191 US banks in 1980-1985. The fourth paper on the right stream path, Berg1992 (Berg et al. 1992), studies productivity growth in banking based on application of a frontier production function within a DEA framework. Berg et al. generalizes the definition of the Malmquist index in the context of cross-section-time-series data. The right stream continues through Berg1993 (Sigbjørn Atle Berg et al. 1993), which exploits the Malmquist indices in Berger et al. (1992) to characterize the 
productivity differences among banks in the Nordic countries, by studying their productivity differences relative to the respective national best practice frontier. Two streams originate from this node - a left-right stream and a right-right stream. The left-right stream begins with Berg1993 and is followed by Athanassopoulos1998 (Athanassopoulos 1998) and evaluates the efficiency of 580 branches of a commercial bank in the UK, distinguishing between market and cost efficiencies. In the next paper, Camanho1999 (Camanho et al. 1999) study the efficiency of Portuguese bank branches and the relationship between size and efficiency, by applying an efficiency-profitability matrix. Portela2005 (Portela and Thanassoulis 2005) applies a newly-developed method to 57 Portuguese bank branches to measure efficiency, and identify the sources of shortfalls in technical and allocative efficiency. Portela2007 (Portela and Thanassoulis 2007) evaluates the performance of the branches of a Portuguese bank over the period 2001-2002 by considering three different areas of performance; fostering the use of new transaction channels; increasing sales and the customer base; and generating profits. Their results suggest positive links between operational and profit efficiency and, also, between transactional and operational efficiency. Portela2007 merges the leftleft stream with the right stream in Soteriou1999 and Giokas2008.

The right-right stream is followed by Favero1995 (Favero and Papi 1995), which derives measures of technical and scale efficiency for 174 Italian banks in 1991. From a methodological perspective, in order to allow for an explicit role of financial capital, Favero1995 modifies the traditional specifications of inputs. Avkiran1999 (Necmi Kemal Avkiran 1999) investigates the effect of a merger on the efficiency of Australian banks over the period 1986-1995. Two one-node branches originate from Favero1995 and merge in Sturm2004 (Sturm and Williams 2004). Avkiran1999 studies the technical efficiency of Portuguese banks over 1990-1995 and compares the relative efficiency of old banks versus new banks, and Sathye2001 (Sathye 2001) measures the X-efficiency of 29 Australian banks in 1990 and compares the efficiency of domestic and foreign banks. Sturm 
and Williams (2004) analyses the efficiency and productivity growth of Australian banks during post-deregulation, and investigates the impact on bank performance of the entry of foreign banks into the country. The path continues through two single-node streams originating from Sturm2004, which join together in Avkiran2010 (Avkiran and Morita 2010). Kirkwood2006 (Kirkwood and Nahm 2006) assesses the cost efficiency of Australian banks over the period 1995-2002 and Avkiran2009 (Avkiran 2009) employs two existing DEA techniques at a sophisticated level; the first applies a slack-based DEA to measure the profit efficiency of United Arab Emirates (UAE) domestic commercial banks in 2005; the second applies a network slack-based DEA to simulated profit centre data, which rely on actual aggregate data for the UAE. Also, Avkiran2010 evaluates a firm compared to its peers from a stakeholder perspective (Avkiran and Morita 2010). The next paper in the right stream, Avkiran2011 (Avkiran 2011), examines the association between efficiency estimates and key financial ratios for Chinese commercial banks. It follows through Barros 2012 where the left stream joins the right stream.

The main path is followed by Juo2012 (Juo et al. 2012), which presents a non-oriented SBM to decompose the change in operating profits into a technical change effect and a profit efficiency effect. To illustrate their application of the approach, they examine a panel of 37 Taiwanese banks over 1994-2002. Yang2013 (Yang and Morita 2013) combines DEA with Nash Bargaining Game (NBG) theory and proposes a method to select an appropriate scheme to improve the efficiency of a bank based on multiple perspectives. The method is applied to a set of 65 Japanese banks.

Kao2014 (Kao and Liu 2014) use a relational network mode to illustrate the idea of multi-period efficiency measurements. After Kao2014, the main path diverges into two single-paper streams: these are the papers at the end of path, published more recently. Avkiran2015 (Avkiran 2015) illustrates dynamic network DEA (DN-DEA) in commercial banking, emphasizing testing robustness in the context of Chinese foreign banks versus domestic banks, between 2008-2010. 
Herrera-Restrepo2016 (Herrera-Restrepo et al., 2016) proposes a multi-step procedure to identify bank branch managerial clusters and to study the operational efficiency of Canadian bank branches.

Thus, most papers in the left stream are branch level studies and the few more recent studies are at bank level. The first few papers in the right stream are bank level studies. Moving forward, in the left-right stream we observe branch level studies while right stream papers are bank level studies in different geographical regions.

Table 5 provides a better understanding of the main characteristics of each paper in the main route by analysing the studies on the main path, based on description of the study sample, select inputs and outputs, and the model and DEA extensions. 
Table 5. Analysis of papers on the main path of banking group

\begin{tabular}{|c|c|c|c|c|c|c|c|c|c|}
\hline \multirow[t]{2}{*}{ Research } & \multicolumn{4}{|c|}{ Evaluated DMUs } & \multicolumn{2}{|l|}{ Input and Outputs } & \multicolumn{3}{|c|}{ Model } \\
\hline & $\begin{array}{l}\text { Geographical } \\
\text { region }\end{array}$ & $\begin{array}{l}\text { Period of } \\
\text { study }\end{array}$ & $\begin{array}{l}\text { No. of } \\
\text { DMUs }\end{array}$ & $\begin{array}{l}\text { Study- } \\
\text { level }\end{array}$ & Input & Output & Approach & Extension & $\begin{array}{l}\text { Efficiency } \\
\text { type }\end{array}$ \\
\hline $\begin{array}{l}\text { Sherman } \\
(1985)\end{array}$ & US & 1982 & 14 & Branch & $\begin{array}{l}\text { Labour, office space and } \\
\text { supply costs }\end{array}$ & Four transaction types & PA & CCR & TE \\
\hline $\begin{array}{l}\text { Rangann et al. } \\
\text { (1988) }\end{array}$ & US & 1986 & 216 & Bank & $\begin{array}{l}\text { Labour, capital, } \\
\text { purchased funds }\end{array}$ & $\begin{array}{l}\text { Real estate loan, commercial } \\
\text { and industrial loans, consumer } \\
\text { loans, demand deposits, time and } \\
\text { saving deposits }\end{array}$ & IA & N/A & $\mathrm{TE}$ \\
\hline $\begin{array}{l}\text { Elyasiani and } \\
\text { Mehdian } \\
\text { (1990) }\end{array}$ & US & $1980-1985$ & 191 & Bank & Deposits, labour and capital & $\begin{array}{l}\text { Real estate loans, commercial } \\
\text { and } \\
\text { industrial loans, other loans }\end{array}$ & IA & CCR & $\begin{array}{l}\text { Rate of TE } \\
\text { change }\end{array}$ \\
\hline $\begin{array}{l}\text { Vassiloglu and } \\
\text { Giokas (1990) }\end{array}$ & Greece & 1987 & 20 & Branch & $\begin{array}{l}\text { Labour, supplies, branch } \\
\text { installation, computer } \\
\text { terminals }\end{array}$ & 4 transaction types & PA & CCR & TE \\
\hline Giokas (1991) & Greece & 1988 & 17 & Branch & $\begin{array}{l}\text { Labour, operating expenses, } \\
\text { utilized branch spaces }\end{array}$ & 3 transaction types & PA & $\begin{array}{l}\mathrm{CCR} \text { and } \\
\mathrm{BCC}\end{array}$ & $\mathrm{TE}$ \\
\hline $\begin{array}{l}\text { Berg et al. } \\
(1992)\end{array}$ & Norway & $1980-1988$ & 152 & Bank & Labour, materials & $\begin{array}{l}\text { Short term loans, long term } \\
\text { loans, deposit }\end{array}$ & VAA & CRS and VRS & $\begin{array}{l}\text { Malmquist } \\
\text { Index (MPI) }\end{array}$ \\
\hline $\begin{array}{l}\text { Berg et al. } \\
\text { (1993) }\end{array}$ & $\begin{array}{l}\text { Finland, } \\
\text { Sweden, } \\
\text { Norway }\end{array}$ & 1990 & 779 & Bank & Labour, capital & Loans, deposit, no. of branches & VAA & CRS and VRS & \\
\hline $\begin{array}{l}\text { Favero and } \\
\text { Papi (1995) }\end{array}$ & Italy & 1991 & 174 & Bank & $\begin{array}{l}\text { A) Labour, capital, current } \\
\text { accounts, saving deposits, } \\
\text { CDs, net funds, financial } \\
\text { capital b) labour, capital, CDs, } \\
\text { net funds, financial capital }\end{array}$ & $\begin{array}{l}\text { a) Loans, investment, non- } \\
\text { interest income b) loans, } \\
\text { investment, non-interest income, } \\
\text { current accounts, saving } \\
\text { deposits, }\end{array}$ & IA, AA & CRS and VRS & TE and SE \\
\hline $\begin{array}{l}\text { Athanassopou } \\
\text { lus (1998) }\end{array}$ & $\begin{array}{l}\text { United } \\
\text { Kingdom }\end{array}$ & & 580 & Branch & $\begin{array}{l}\text { a) Numbers of transactions, } \\
\text { potential market, sales } \\
\text { representatives, internal } \\
\text { automatic facilities, branch } \\
\text { outlets in the surrounding area } \\
\text { b) direct labour costs, total } \\
\text { technology facilities }\end{array}$ & $\begin{array}{l}\text { a) Liabilities sales, loans and } \\
\text { mortgages, insurance and } \\
\text { securities, no. of cards b) no. of } \\
\text { transactions, liability sales, loans } \\
\text { and mortgages, insurance and } \\
\text { securities, no. of cards }\end{array}$ & IA & CRS and VRS & $\mathrm{ME}$ and SE \\
\hline
\end{tabular}




\begin{tabular}{|c|c|c|c|c|c|c|c|c|c|}
\hline $\begin{array}{l}\text { Thanassoulis } \\
\text { (1999) }\end{array}$ & $\begin{array}{l}\text { United } \\
\text { Kingdom and } \\
\text { Finland }\end{array}$ & $\mathrm{n} / \mathrm{a}$ & $\mathrm{n} / \mathrm{a}$ & Branch & $\begin{array}{l}\text { a) Production efficiency for } \\
\text { UK branch: direct staff costs } \\
\text { b) production efficiency for } \\
\text { Finland branch: numbers of } \\
\text { human tellers,computer } \\
\text { terminals,branches, TMs c) } \\
\text { market efficiency: numbers } \\
\text { of facilities, umbers of sales } \\
\text { persons, opening hours, } \\
\text { markets, existing customers, } \\
\text { transactions }\end{array}$ & $\begin{array}{l}\text { a) Production efficiency for UK } \\
\text { branch: Numbers of mortgage } \\
\text { applications,insurance policies } \\
\text { sold,new saving accounts, } \\
\text { transactions, b) Production } \\
\text { efficiency for Finland branch: } \\
\text { Numbers of transactions by } \\
\text { humans, cash withdrawals,loans } \\
\text { processed, transactions by teller } \\
\text { machine, c) market efficiency: } \\
\text { mortgage policies, insurance } \\
\text { sales, saving accounts }\end{array}$ & $\mathrm{n} / \mathrm{a}$ & CRS & $\mathrm{ME}$ and $\mathrm{PE}$ \\
\hline $\begin{array}{l}\text { Golany and } \\
\text { Storbeck } \\
\text { (1999) }\end{array}$ & US & $1992-1993$ & 182 & Branch & Labour, branch facilities & $\begin{array}{l}\text { Market size, economic status of } \\
\text { area, competitive activities }\end{array}$ & IA & CRS & $\mathrm{OE}$ \\
\hline $\begin{array}{l}\text { Avkiran } \\
(1999)\end{array}$ & Australia & 1986-1995 & 19 & Bank & $\begin{array}{l}\text { Staff numbers, deposits, } \\
\text { interest expense and non- } \\
\text { interest expense }\end{array}$ & $\begin{array}{l}\text { Net loans, net interest income, } \\
\text { and non-interest income }\end{array}$ & IA & CRS & $\mathrm{XE}$ \\
\hline $\begin{array}{l}\text { Camanho and } \\
\text { Dyson (1999) }\end{array}$ & Portugal & 1996 & 168 & Branch & $\begin{array}{l}\text { Number of employees in the } \\
\text { branch, floor space of the } \\
\text { branch, operational costs, } \\
\text { number of external ATMs }\end{array}$ & $\begin{array}{l}\text { Numbers of general service } \\
\text { transactions performed by } \\
\text { branch staff, transactions in } \\
\text { external ATMs, types of } \\
\text { accounts at the branch, and value } \\
\text { of savings and loans }\end{array}$ & IA & CRS and VRS & TE and SE \\
\hline $\begin{array}{l}\text { Soteriou and } \\
\text { Zenios (1999) }\end{array}$ & Cyprus & $\mathrm{n} / \mathrm{a}$ & 144 & Branch & $\begin{array}{l}\text { For all three types of } \\
\text { efficiency; Resources } \\
\text { (managerial personnel, } \\
\text { clerical personnel, computer } \\
\text { space), micro-environment } \\
\text { (current accounts, saving } \\
\text { accounts, foreign currency } \\
\text { and commercial accounts, } \\
\text { credit applications, } \\
\text { commissions) }\end{array}$ & $\begin{array}{l}\text { Operational efficiency: incident } \\
\text { duration, waiting time, credit } \\
\text { approval rate; service quality: } \\
\text { reliability, responsiveness, } \\
\text { assurance, tangibles, empathy; } \\
\text { profitability efficiency: profit }\end{array}$ & IA, PA & CCR & $\begin{array}{l}\text { OE, Service } \\
\text { Quality } \\
\text { Efficiency, } \\
\text { PE }\end{array}$ \\
\hline Sathye (2001) & Australia & 1996 & 29 & Bank & Labour, capital, loanable unds & Loans, demand deposits & IA & $\mathrm{n} / \mathrm{a}$ & TE, AE, CE \\
\hline $\begin{array}{l}\text { Canhoto and } \\
\text { Dermine } \\
\text { (2003) }\end{array}$ & Portugal & $1990-1995$ & 20 & Bank & $\begin{array}{l}\text { Number of employees, } \\
\text { physical capital }\end{array}$ & $\begin{array}{l}\text { Loans, deposits, securities, } \\
\text { interbank assets/liabilities, } \\
\text { number of branches }\end{array}$ & IA & CRS and VRS & $\mathrm{TE}$ \\
\hline $\begin{array}{l}\text { Sturm and } \\
\text { Williams } \\
\text { (2004) }\end{array}$ & Australia & $1988-2001$ & & & $\begin{array}{l}\text { Model 1: inputs: employees, } \\
\text { deposits, equity capital. } \\
\text { outputs: Model 2: interest } \\
\text { expenses, non-interest } \\
\text { expenses. }\end{array}$ & $\begin{array}{l}\text { Model 1: loans, off-balance } \\
\text { sheet items. Model 2: net interest } \\
\text { income, non-interest income. }\end{array}$ & IA & CRS and VRS & PTE, TE, SE \\
\hline
\end{tabular}




\begin{tabular}{|c|c|c|c|c|c|c|c|c|c|}
\hline $\begin{array}{l}\text { Paradi and } \\
\text { Schaffnit } \\
\text { (2004) }\end{array}$ & Canada & 1995 & 90 & Branch & $\begin{array}{l}\text { Production: staff, equipment, } \\
\text { premises usage, other non- } \\
\text { interest expenses; strategic } \\
\text { non-accrual loans }\end{array}$ & $\begin{array}{l}\text { Production: deposits, loans, } \\
\text { operating services, and account } \\
\text { maintenance; strategic: deposits, } \\
\text { loans and operating services }\end{array}$ & IA & CRS and VRS & TE, SC \\
\hline $\begin{array}{l}\text { Portela \& } \\
\text { Thanassoulis } \\
, 2005\end{array}$ & Portugal & 2001 & 57 & Branch & No. of staff, supply costs & $\begin{array}{l}\text { Value current accounts. Value } \\
\text { other sources, value credit by } \\
\text { bank, value credit associates }\end{array}$ & IA & VRS & PRE, TE \\
\hline $\begin{array}{l}\text { Kirkwood and } \\
\text { Nahm (2006) }\end{array}$ & Australia & $1995-2002$ & 10 & Bank & $\begin{array}{l}\text { Service efficiency: Number of } \\
\text { full-time equivalent } \\
\text { employees interest-bearing } \\
\text { assets, property, plant and } \\
\text { equipment, non-interest } \\
\text { income interest-bearing } \\
\text { liabilities }\end{array}$ & $\begin{array}{l}\text { Service Efficiency: interest } \\
\text { bearing asset, non-interest } \\
\text { income; profit efficiency: profit } \\
\text { before tax and abnormal items }\end{array}$ & IA & CRS and VRS & $\begin{array}{l}\text { TE, AE, } \\
\text { Banking } \\
\text { Service } \\
\text { Efficiency }\end{array}$ \\
\hline $\begin{array}{l}\text { Portela and } \\
\text { Thanassoulis } \\
\text { (2007) }\end{array}$ & Portugal & $2001-2002$ & 57 & Branch & $\begin{array}{l}\text { Transactional efficiency: } \\
\text { Number ATMs, Rent, No. } \\
\text { clients not registered; } \\
\text { operational efficiency: } \\
\text { Number of staff, rent; profit } \\
\text { efficiency: Number of staff, } \\
\text { supply costs }\end{array}$ & $\begin{array}{l}\text { Transactional efficiency: } \\
\text { numbers of new registrations for } \\
\text { internet use, transactions in } \\
\text { CATs, deposits in ETM } \\
\text { (ATMs+CATs); operational } \\
\text { efficiency: } \\
\Delta \text { number of clients, } \Delta \text { value } \\
\text { current accounts, } \Delta \text { value other } \\
\text { resources, } \Delta \text { value titles } \\
\text { deposited, } \Delta \text { value credit by } \\
\text { bank, } \Delta \text { value credit by } \\
\text { associates, number transactions ; } \\
\text { profit efficiency: value current } \\
\text { accounts, value other resources, } \\
\text { value credit over bank, value } \\
\text { credit associates }\end{array}$ & IA & VRS & $\begin{array}{l}\text { PRE, } \\
\text { Transactional } \\
\text { Efficiency, } \\
\text { OE }\end{array}$ \\
\hline Giokas (2008) & Greece & 2002 & 44 & Branch & $\begin{array}{l}\text { Production efficiency and } \\
\text { transaction efficiency: } \\
\text { personnel costs, running and } \\
\text { other operating costs } \\
\text { intermediation efficiency: } \\
\text { interest costs, non-interest } \\
\text { costs }\end{array}$ & $\begin{array}{l}\text { Production efficiency: value of } \\
\text { loan portfolio, value of deposits, } \\
\text { non-interest income; transaction } \\
\text { efficiency: loan transactions, } \\
\text { deposit transactions, remaining } \\
\text { transactions; intermediation } \\
\text { efficiency: interest income, non- } \\
\text { interest income }\end{array}$ & IA & VRS & $\mathrm{PE}$ \\
\hline
\end{tabular}




\begin{tabular}{|c|c|c|c|c|c|c|c|c|c|}
\hline $\begin{array}{l}\text { Avkiran } \\
(2009)\end{array}$ & UAE & 2005 & 15 & Bank & $\begin{array}{l}\text { Interest expense, Non-interest } \\
\text { expense a }\end{array}$ & $\begin{array}{l}\text { Interest income, non-interest } \\
\text { income }\end{array}$ & IA & $\begin{array}{l}\text { VRS-SBM, } \\
\text { NSBM }\end{array}$ & PRE \\
\hline $\begin{array}{l}\text { Siriopoulos } \\
\text { and Tziogkidis } \\
(2010)\end{array}$ & Greece & $1995-2003$ & 10 & Bank & $\begin{array}{l}\text { Financial analysis approach: } \\
\text { unit vector as inputs ; credit } \\
\text { approach: personnel expenses, } \\
\text { provisions and operational } \\
\text { expenses }\end{array}$ & $\begin{array}{l}\text { Financial analysis approach: } \\
\text { return on equity, financial } \\
\text { independence ratio, gross } \\
\text { operating margin, asset turnover } \\
\text { ratio, service concentration } \\
\text { index; credit approach: financial } \\
\text { claims, operational income and } \\
\text { earnings before taxes (EBT) } \\
\text { divided by total assets }\end{array}$ & $\begin{array}{l}\text { Financial } \\
\text { credit } \\
\text { approach, } \\
\text { credit } \\
\text { approach }\end{array}$ & CRS and VRS & TE, PE \\
\hline $\begin{array}{l}\text { Avkiran and } \\
\text { Morita (2010) }\end{array}$ & China & 2007 & 20 & Bank & $\begin{array}{l}\text { Shareholders perspective: } \\
\text { Credit quality } \\
\text { (equity/impaired loans } \\
(\%) \text { ); customers perspective: } \\
\text { profitability (ROAE }(\%) \text { ), } \\
\text { efficiency (income/cost }(\%) \text {, } \\
\text { value (dividend pay-out per } \\
\text { share); management } \\
\text { perspective: credit quality, } \\
\text { value; employees perspective: } \\
\text { efficiency, value }\end{array}$ & $\begin{array}{l}\text { Shareholders perspective: } \\
\text { soundness (capital adequacy } \\
\text { ratio }(\%) \text { ), profitability, } \\
\text { efficiency, value; customers } \\
\text { perspective: profitability, } \\
\text { efficiency, value; management } \\
\text { perspective: soundness, } \\
\text { profitability, efficiency; } \\
\text { employees perspective: } \\
\text { soundness, credit quality, } \\
\text { profitability; regulators } \\
\text { perspective: soundness, credit } \\
\text { quality, profitability, efficiency, } \\
\text { value; }\end{array}$ & $\mathrm{n} / \mathrm{a}$ & VRS & $\begin{array}{l}\text { Range- } \\
\text { adjusted } \\
\text { additive } \\
\text { measure } \\
\text { (RAM super- } \\
\text { efficiency } \\
\text { RAM } \\
\text { (SRAM) } \\
\text { score), }\end{array}$ \\
\hline $\begin{array}{l}\text { Paradi and } \\
\text { Rouatt (2011) }\end{array}$ & Canada & & 816 & Branch & $\begin{array}{l}\text { Production approach: No of } \\
\text { full time equivalent personnel; } \\
\text { profitability approach: fund } \\
\text { resources in } \$ \text { values } \\
\text {;intermediation approach: } \\
\text { expenses in } \$ \text { values }\end{array}$ & $\begin{array}{l}\text { Production approach: No. of } \\
\text { transactions; profitability } \\
\text { approach: earning assets in } \$ \\
\text { value ;intermediation approach: } \\
\text { revenues in } \$ \text { values }\end{array}$ & $\begin{array}{l}\text { PA,PRA, } \\
\text { IA }\end{array}$ & $\begin{array}{l}\text { Modified } \\
\text { VRS-SBM }\end{array}$ & $\begin{array}{l}\text { PE, PE, } \\
\text { International } \\
\text { Efficiency }\end{array}$ \\
\hline
\end{tabular}




\begin{tabular}{|c|c|c|c|c|c|c|c|c|c|}
\hline $\begin{array}{l}\text { Avkiran } \\
\text { (2011) }\end{array}$ & China & $2007-2008$ & 38 & Bank & $\begin{array}{l}\text { Core profitability model: } \\
\text { Total interest expense, Total } \\
\text { non-interest expenses; } \\
\text { expanded profitability model: } \\
\text { interest expense on customer } \\
\text { deposits, other interest } \\
\text { expense, personnel expenses, } \\
\text { other operating expenses; } \\
\text { financial ratio model: } \\
\text { reciprocal of capital adequacy } \\
\text { ratio, impaired loans/net } \\
\text { interest income, impaired } \\
\text { loans/total assets, impaired } \\
\text { loans/equity, reciprocal of } \\
\text { dividends per share, reciprocal } \\
\text { of growth rate of assets }\end{array}$ & $\begin{array}{l}\text { Core profitability model: gross } \\
\text { interest and dividend income, } \\
\text { total non-interest operating } \\
\text { income, expanded profitability } \\
\text { model: interest income on loans, } \\
\text { other interest income, net fees } \\
\text { and commissions, other } \\
\text { operating income ; financial } \\
\text { ratio model: growth rate of } \\
\text { earnings per share, return on } \\
\text { average equity, post-tax } \\
\text { profit/average total assets, net } \\
\text { interest income/average total } \\
\text { assets, price to earnings ratio }\end{array}$ & IA & $\begin{array}{l}\text { SBM, Super } \\
\text { VRS-SBM }\end{array}$ & $\begin{array}{l}\text { Core Profit } \\
\text { Efficiency, } \\
\text { Expanded } \\
\text { Profit } \\
\text { Efficiency, } \\
\text { Financial } \\
\text { Ratio } \\
\text { Efficiency }\end{array}$ \\
\hline $\begin{array}{l}\text { Barros et al. } \\
(2012)\end{array}$ & Japan & $2002-2007$ & 888 & Bank & $\begin{array}{l}\text { Number of employees, } \\
\text { deposits, premises }\end{array}$ & Securities, loans, bad loans & IA & TE & WRDDM \\
\hline $\begin{array}{l}\text { Juo et al. } \\
\text { (2012(tAIWA } \\
\text { N dOLLAR)) }\end{array}$ & Taiwan & $1994-2002$ & 37 & Bank & $\begin{array}{l}\text { Borrowed funds, labour, fixed } \\
\text { assets; unit prices: average } \\
\text { interest paid per TWD } \\
\text { (Taiwan Dollar) of borrowed } \\
\text { funds, ratio of labour cost to } \\
\text { the number of staff, non- } \\
\text { labour operational cost per } \\
\text { TWD of fixed assets }\end{array}$ & $\begin{array}{l}\text { Financial investments, loans; } \\
\text { unit prices: average interest } \\
\text { earned per TWD of investment, } \\
\text { average interest earned per TWD } \\
\text { of loans }\end{array}$ & IA & PRE change & $\begin{array}{l}\text { Non-oriented } \\
\text { SBM, BCC }\end{array}$ \\
\hline $\begin{array}{l}\text { Yang and } \\
\text { Morita (2013) }\end{array}$ & Japan & $2001-2006$ & 65 & Bank & $\begin{array}{l}\text { Shareholder perspective: } \\
\text { efficiency; customer } \\
\text { perspective: credit quality, } \\
\text { profitability, valuation; } \\
\text { management perspective: } \\
\text { efficiency, valuation; } \\
\text { employee perspective: credit } \\
\text { quality, valuation }\end{array}$ & $\begin{array}{l}\text { Shareholder perspective: } \\
\text { soundness, credit quality, } \\
\text { profitability, valuation; customer } \\
\text { perspective: soundness, } \\
\text { profitability; management } \\
\text { perspective: soundness, credit } \\
\text { quality, profitability; employee } \\
\text { perspective: soundness, } \\
\text { profitability, efficiency }\end{array}$ & $\mathrm{n} / \mathrm{a}$ & $\mathrm{n} / \mathrm{a}$ & DEA+NBG \\
\hline $\begin{array}{l}\text { Kao and Liu } \\
\text { (2014) }\end{array}$ & Taiwan & $2009-2011$ & 22 & Bank & $\begin{array}{l}\text { Labour, physical capital, } \\
\text { purchased funds }\end{array}$ & $\begin{array}{l}\text { Demand deposits, short-term } \\
\text { loans, medium-and-long-term } \\
\text { loans }\end{array}$ & IA & CRS & $\begin{array}{l}\text { Rational } \\
\text { network } \\
\text { efficiency, } \\
\text { connected } \\
\text { network } \\
\text { efficiency, } \\
\text { aggregate } \\
\text { efficiency }\end{array}$ \\
\hline
\end{tabular}




\begin{tabular}{|l|l|l|l|l|l|l|l|}
\hline $\begin{array}{l}\text { Avkiran } \\
(2015)\end{array}$ & China & 2008-2010 & 144 & Bank & $\begin{array}{l}\text { Interest expenses on customer } \\
\text { deposits, other interest } \\
\text { expenses, personnel expenses, } \\
\text { other operating expense }\end{array}$ & $\begin{array}{l}\text { Interest income on loans, other } \\
\text { interest income, net fees and } \\
\text { commissions, other operating } \\
\text { income }\end{array}$ & $\begin{array}{l}\text { IA } \\
\text { W-VRS non- } \\
\text { oriented } \\
\text { dynamic } \\
\text { NSBM }\end{array}$ \\
\hline $\begin{array}{l}\text { Herrera- } \\
\text { Restrepo et } \\
\text { al. (2016) }\end{array}$ & Canada & 2004 & 966 & Branch & $\begin{array}{l}\text { Full-time equivalent } \\
\text { service, sales, and } \\
\text { management employees }\end{array}$ & $\begin{array}{l}\text { Day-to-day, investment, } \\
\text { borrowing, and over-the- } \\
\text { counter transactions }\end{array}$ \\
\hline
\end{tabular}

PA: Production Approach, IA: Intermediation Approach, VAA: Value Added Approach, PRA: Profitability Approach

CRS: Constant Return to Scale; VRS: Variable Return to Scale; TE: Technical Efficiency; SE: Scale Efficiency; ME: Market Efficiency; CE: Cost-Efficiency; PE: Production Efficiency; PRE: Profit Efficiency; OE: Operational Efficiency AE: Allocative Efficiency; PTE: Pure Technical Efficiency; XE: X Efficiency; SBM: Slacks Based Measure; NSBM: Network Slacks Based Measure; WSBM: Weighted Slacks

Based Measure; WRDDM: Weighted Russell directional distance model; NBG: Nash Bargaining Game 
Table 5 shows out of 33 papers, on the main path 13 papers are branch-level studies and the others are bank-level studies. With the exception of Berg1993 and Thanassoulis1999, which study multi-country banking industry efficiency, the remaining papers focus on single-country data. Barros, Managi, and Matousek (2012) have studied the largest number of DMUs while Kirkwood2006 (Kirkwood \& Nahm, 2006) and Siriopoulos2010 (Siriopoulos \& Tziogkidis, 2010) study the smallest number of DMUs. Some authors have contributed more than one paper to the main path. Avkiran is the author of five papers on the path and Berg, Camanho and Paradi are first authors of two papers each, on the main path. 19 out of 33 papers on the main path apply an intermediation approach to the evaluation of evaluating DMUs, which shows the wide use of this approach compared to alternatives.

\subsection{Money market fund main path}

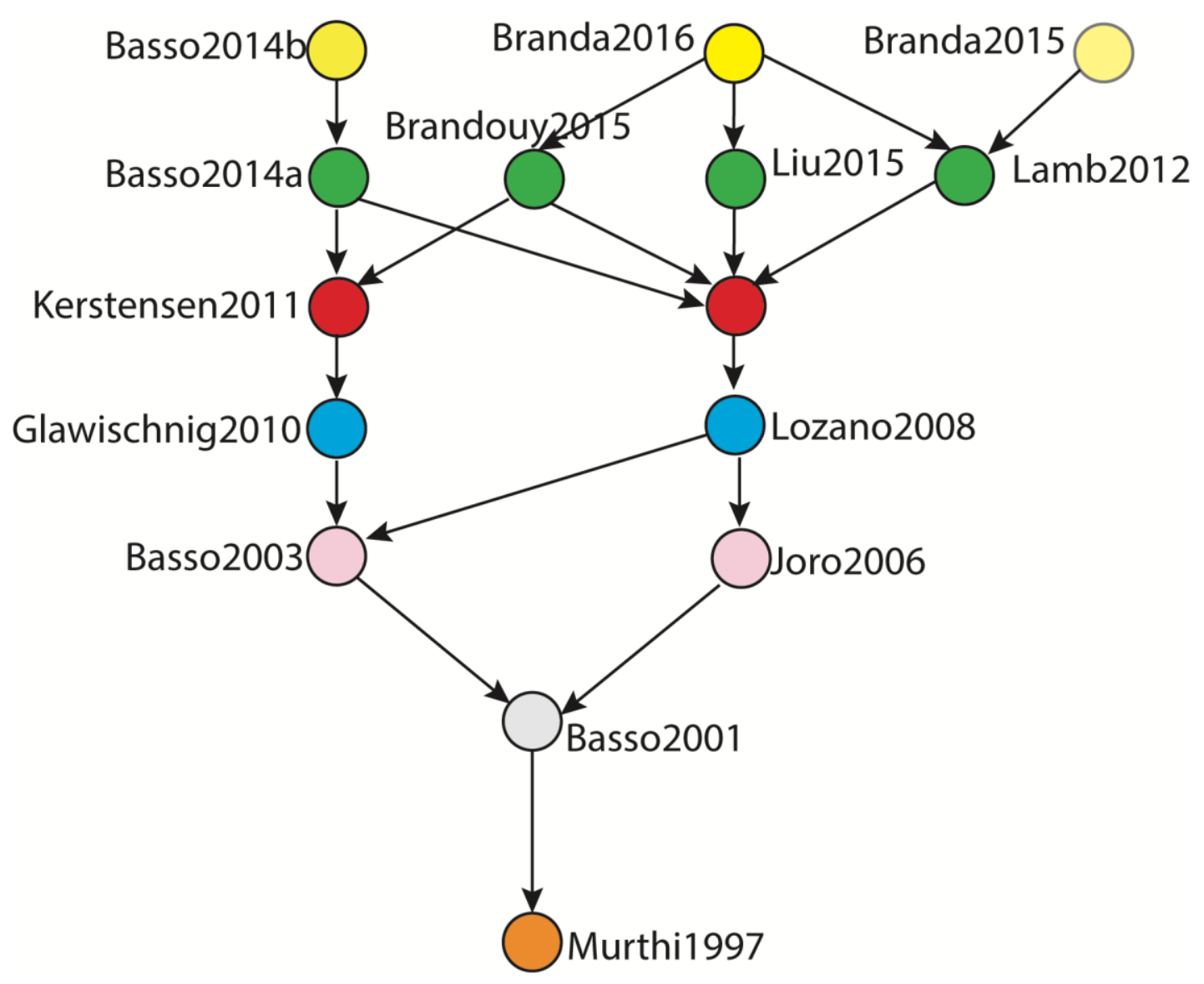




\section{Figure 4. Money market funds main path}

Figure 4 depicts the main path of the money market funds group. This path starts with a paper by Murthi1997 (Murthi et al. 1997), which introduces a new index to measure the performance of fund portfolios. There are two frequently used indices for assessing portfolio performance, Jensen's alpha (Jensen 1968) and the Sharpe index (Sharpe 1966). Murthi1997 proposes the DEA Portfolio Efficiency Index (DPEI) to address some additional issues. The authors compare the DPEI to traditional indices, applying them to 2,083 mutual funds in the third quarter of 1993 . They also use 33 categories of funds, and evaluate DPEI to study the sources of variation in the means of DPEI across different categories, employing regression analysis.

Basso2001 (Basso and Funari 2001) is the next paper on the main path. There are four papers by Basso2001 on the main path, which is indicative of the significance of their work in the literature. Basso2001 defines new mutual fund performance indexes. Applying DEA allows these new indexes to take account of several inputs and outputs not considered by the traditional indexes. They apply their new model to 47 different classes of Italian mutual funds (stock funds, balanced funds and bonds funds) from January 1997 to end June 1999.

The main path then divides into two streams. We start with left stream, which begins with Basso2003 (Basso and Funari 2003). This paper presents a few models for measuring the performance of ethical mutual funds to consider their ethical components, expected returns, investment risk and subscription and redemption costs. The next two papers are Lozano2008 (Lozano \& Gutiérrez, 2008), in the right-hand stream, and Glawischnig2010 (Glawischnig and Sommersguter-Reichmann 2010), in the left hand stream. Both provide critiques of DEA-based performance indexes to measure alternative investment fund performance. Although this new DEA-based performance index has the advantage that it considers multiple inputs (risk) and multiple outputs (returns), the author shows that this single real number performance index does 
not include all the relevant information, overlooking, for instance, the amount of inefficiency in the factors, the importance of reference funds, and the endogenously derived weights. The authors show that a DEA-based index cannot replace financial performance indexes; however, these types of indexes provide new insights into the performance measurement of alternative investment funds. The paper by Kerstens2011 (Kerstens et al. 2011) is motivated by specification issues surrounding applications of non-parametric frontier models, for measuring the performance of mutual funds, and argues for the use of a shortage function and robust L-moment (Hosking, 1990), which are a novelty in frontier studies of mutual funds; 1,070 mutual funds taken from US and EU databases are employed to illustrate the assumptions underlying the modelling.

The stream continues through Basso2014a (Basso and Funari 2014a), where the right and left streams merge. Basso2014a proposes some new models to assess the performance of Socially Responsible Investment (SRI) funds. The authors investigate the presence of returns to scale in European SRI equity funds and compare the performance of SRI and non-SRI funds.

The right stream continues through Joro2006 (Joro and $\mathrm{Na} 2006$ ), which develops a DEA framework for portfolio performance assessment, based on mean-variance-skewness. It provides an empirical illustration based on 58 mutual funds. Lozano2008 (Lozano and Gutiérrez 2008) introduce six DEA-like linear programming models to measure the relative efficiency of mutual funds consistent with second-order stochastic dominance. Two of the proposed models are meansafety models while the remaining four are mean-risk types. These models are applied to 18 Spanish mutual funds over 2002-2005. The next paper in the right stream is Lamb2012a (Lamb and Tee 2012a), which introduces a stochastic DEA model by applying the bootstrap method to develop techniques for ranking funds and deriving confidence intervals. The authors demonstrate use of the bootstrap model to deal with the issues of substantial bias in investment fund performance, correlation in funds returns and accuracy of DEA estimates. They identify the need 
for a DEA model based on a risk-returns ratio to gauge the performance of investment funds. They discuss how to handle scope for diversification and the relationship between diversification, coherent risk measures and stochastic dominance.

From Lamb2012a, the right stream splits into three short streams. The far right stream, Lamb2012, (Lamb and Tee 2012b) shows that efficiency estimates of investment fund performance using DEA models, typically show substantial bias, which is greater for high-risk, high-returns funds compared to low-risk, low-returns funds. Lamb and Tee develop a stochastic DEA model to deal with consistency, bias and correlation in funds' returns, by applying the bootstrap method. A sample of 60 monthly returns from 30 hedge funds during the period 2000-2004, is used to illustrate the proposed model. The next paper, Branda2015 (Branda 2015), proposes a new diversification-consistent DEA model which uses several risk measures as inputs and return measures as outputs, with both positive and negative values. They identify various models with different levels of Pareto-Koopmans efficient investment opportunities. They experiment using 48 representative industry portfolios from US stock markets. The paper positioned in the middle, Liu2015 (Liu et al. 2015), investigates the theoretical foundations of DEA models for portfolios, from the perspective of the sampling portfolio. They conduct comprehensive simulations and show that, with adequate data sets, the classic DEA model can be an effective tool to compute the portfolio efficiency in their performance assessments. This study confirms the effectiveness and practicality of the DEA method for assessing portfolio efficiency. The far left stream includes Brandouy2015 (Brandouy et al. 2015), which conducts a three part analysis to compare recent convex and non-convex frontier mutual fund rating models to traditional models. The authors conclude that frontier-based mutual fund ratings allow the design of investment policies which give better performance and which are more coherent and consistent compared to traditional financial performance measures. 
These three short streams merge in Branda2016 (Branda 2016), which introduces a new diversification-consistent DEA model based on directional distance measure, and proposes reformulations under distributional assumptions, which allow efficient problem solving using second-order cone and mixed-integer linear programming. By considering inputs as value at risk on several levels, this diversification allows for risk-shaping based on multi-objective optimization and Pareto-Koopmans efficiency. The proposed model is an appropriate normal and finite discrete distribution of returns from a feasibility, optimal solutions and reformulations perspectives.

Table 6 summarizes the 15 papers on the main path in the money market group. Table 3 presents the geographical distribution of the money market papers. Four out of ten papers on the main path are by Basso and Funari (2003; 2001, 2014a, 2014b). Most of the papers on the money market main path apply DEA to propose a new index to measure the performance of money market funds especially mutual funds. 
Table 6. Analysis of papers on the main path of money market fund group

\begin{tabular}{|c|c|c|c|c|c|c|c|c|}
\hline \multirow[t]{2}{*}{ Research } & \multicolumn{4}{|c|}{ Evaluated DMUs } & \multicolumn{2}{|c|}{ Input and Outputs } & \multicolumn{2}{|l|}{ Model } \\
\hline & $\begin{array}{l}\text { Geographi } \\
\text { cal Region }\end{array}$ & $\begin{array}{l}\text { Period } \\
\text { of study }\end{array}$ & $\begin{array}{l}\text { No. } \\
\text { of } \\
\text { DM } \\
\text { Us }\end{array}$ & $\begin{array}{l}\text { Type of } \\
\text { Money } \\
\text { market }\end{array}$ & Input & Output & $\begin{array}{l}\text { Orientati } \\
\text { on }\end{array}$ & $\begin{array}{l}\text { Proposed } \\
\text { model }\end{array}$ \\
\hline $\begin{array}{l}\text { Murthi et al. } \\
\text { (1997) }\end{array}$ & US & $\begin{array}{l}\text { 3rd } \\
\text { quarter } \\
1993\end{array}$ & 2083 & $\begin{array}{l}\text { Mutual } \\
\text { Funds }\end{array}$ & $\begin{array}{l}\text { Expense } \\
\text { ratio, } \\
\text { Load, } \\
\text { Turnover, } \\
\text { Standard } \\
\text { deviation }\end{array}$ & Return & $\begin{array}{l}\text { Output- } \\
\text { orientatio } \\
n\end{array}$ & $\begin{array}{l}\text { DEA } \\
\text { portfolio } \\
\text { efficiency } \\
\text { index (DPEI) } \\
\text { (multiple } \\
\text { input-single } \\
\text { output) }\end{array}$ \\
\hline $\begin{array}{l}\text { Basso and } \\
\text { Funari } \\
(2001)\end{array}$ & Italy & $\begin{array}{l}\text { January } \\
1997 \text { to } \\
\text { June } \\
1999\end{array}$ & 47 & $\begin{array}{l}\text { Mutual } \\
\text { Funds }\end{array}$ & $\begin{array}{l}\text { Square } \\
\text { root of the } \\
\text { half- } \\
\text { variance } \\
\text { and the } \beta \text { - } \\
\text { coefficient }\end{array}$ & $\begin{array}{l}\text { Expected } \\
\text { return, } \\
\text { stochastic } \\
\text { dominance }\end{array}$ & $\begin{array}{l}\text { Input- } \\
\text { orientatio } \\
n\end{array}$ & $\begin{array}{l}\text { DEA indexes } \\
\text { (IDEA_1 and } \\
\text { IDEA_2) } \\
\text { reflecting the } \\
\text { investors' } \\
\text { preference } \\
\text { structure and } \\
\text { the time } \\
\text { occurrence of } \\
\text { the returns } \\
\text { (multiple } \\
\text { input- } \\
\text { multiple } \\
\text { output) }\end{array}$ \\
\hline $\begin{array}{l}\text { Basso and } \\
\text { Funari } \\
(2003)\end{array}$ & N/A & N/A & 50 & $\begin{array}{l}\text { Simulated } \\
\text { Mutual } \\
\text { Funds }\end{array}$ & $\begin{array}{l}3 \text { brackets } \\
\text { of } \\
\text { subscripti } \\
\text { on costs, } 3 \\
\text { brackets } \\
\text { of } \\
\text { redemptio } \\
\text { n costs, } 2 \\
\text { risk } \\
\text { measures }\end{array}$ & $\begin{array}{l}2 \text { outputs } \\
\text { considered } \\
: \text { expected } \\
\text { return and } \\
\text { an ethical } \\
\text { indicator }\end{array}$ & $\begin{array}{l}\text { Input and } \\
\text { output } \\
\text { orientatio } \\
\mathrm{n}\end{array}$ & $\begin{array}{l}\text { DEA model } \\
\text { considering } \\
\text { the ethical } \\
\text { aims as a } \\
\text { second } \\
\text { objective } \\
\text { besides the } \\
\text { investment } \\
\text { return }\end{array}$ \\
\hline $\begin{array}{l}\text { Joro and } \mathrm{Na} \\
(2006)\end{array}$ & US & $\begin{array}{l}\text { January } \\
1995 \text { to } \\
\text { April } \\
2000\end{array}$ & 54 & $\begin{array}{l}\text { Mutual } \\
\text { Funds }\end{array}$ & Variance & $\begin{array}{l}\text { Return, } \\
\text { skewness }\end{array}$ & $\begin{array}{l}\text { Input- } \\
\text { orientatio } \\
n\end{array}$ & $\begin{array}{l}\text { Portfolio } \\
\text { performance } \\
\text { measure } \\
\text { based on } \\
\text { mean- } \\
\text { variance- } \\
\text { skewness } \\
\text { framework }\end{array}$ \\
\hline $\begin{array}{l}\text { Lozano and } \\
\text { Gutuerrez } \\
(2008)\end{array}$ & Spain & $\begin{array}{l}\text { January } \\
2002 \text { to } \\
\text { Decemb } \\
\text { er } 2005\end{array}$ & 108 & $\begin{array}{l}\text { Mutual } \\
\text { Funds }\end{array}$ & $\begin{array}{l}\text { Return- } \\
\text { risk } \\
\text { models: } \\
\text { return; } \\
\text { return- } \\
\text { safety } \\
\text { model: } \\
\text { constant* }\end{array}$ & $\begin{array}{l}\text { Return- } \\
\text { risk } \\
\text { models: } \\
\text { risk; } \\
\text { return- } \\
\text { safety } \\
\text { model: } \\
\text { return and } \\
\text { safety }\end{array}$ & N/A & $\begin{array}{l}\text { Six distinct } \\
\text { DEA-like } \\
\text { linear } \\
\text { programmin } \\
\text { g models; (4 } \\
\text { return-risk } \\
\text { DEA models } \\
\text { plus } 2 \\
\text { return-safety } \\
\text { DEA) }\end{array}$ \\
\hline
\end{tabular}




\begin{tabular}{|c|c|c|c|c|c|c|c|c|}
\hline $\begin{array}{l}\text { Glawischni } \\
\text { (2010) }\end{array}$ & N/A & N/A & 167 & $\begin{array}{l}\text { Managed } \\
\text { Future } \\
\text { Fund }\end{array}$ & $\begin{array}{l}\text { Investmen } \\
\mathrm{t} \text { risk } \\
\text { measured } \\
\text { in terms } \\
\text { of } \\
\text { standard } \\
\text { deviation, } \\
\text { lower } \\
\text { partial } \\
\text { moments } \\
\text { (LPMs 0- } \\
4) .\end{array}$ & $\begin{array}{l}\text { Compoun } \\
\text { ded return } \\
\text { to upper } \\
\text { partial } \\
\text { moments } \\
\text { (UPMs 1- } \\
\text { 4) and } \\
\text { maximum } \\
\text { drawdown } \\
\text { periods } \\
\text { (MDP) }\end{array}$ & $\begin{array}{l}\text { Input and } \\
\text { Output } \\
\text { orientatio } \\
n\end{array}$ & $\begin{array}{l}\text { DEA-based } \\
\text { performance } \\
\text { assessment } \\
\text { models been } \\
\text { investigated } \\
\text { to see } \\
\text { whether can } \\
\text { meet all the } \\
\text { desirable } \\
\text { properties } \\
\text { usually } \\
\text { attributed to } \\
\text { DEA-based } \\
\text { evaluation }\end{array}$ \\
\hline $\begin{array}{l}\text { Kerstens } \\
\text { (2011) }\end{array}$ & US and EU & $\begin{array}{l}\text { January } \\
2,2004 \\
\text { to } \\
\text { Februar } \\
\text { y 28, } \\
2009\end{array}$ & 1068 & $\begin{array}{l}\text { Mutual } \\
\text { Funds }\end{array}$ & Risk & Return & N/A & $\begin{array}{l}\text { Discussing } \\
\text { (i) the nature } \\
\text { of returns to } \\
\text { scale, (ii) the } \\
\text { inclusion of } \\
\text { higher } \\
\text { moments } \\
\text { and cost } \\
\text { components, } \\
\text { and (iii) } \\
\text { imposing } \\
\text { convexity or } \\
\text { not for DEA } \\
\text { in context of } \\
\text { mutual } \\
\text { funds } \\
\text { models }\end{array}$ \\
\hline $\begin{array}{l}\text { Lamb and } \\
\text { Tee (2012a) }\end{array}$ & Global & $\begin{array}{l}2000 \\
\text { and } \\
2004\end{array}$ & 30 & $\begin{array}{l}\text { Mutual } \\
\text { Funds }\end{array}$ & $\begin{array}{l}\text { Nonnegat } \\
\text { ive Risk } \\
\text { measures }\end{array}$ & $\begin{array}{l}\text { Return } \\
\text { measures }\end{array}$ & $\begin{array}{l}\text { Input- } \\
\text { orientatio } \\
\mathrm{n}\end{array}$ & $\begin{array}{l}\text { An iterative } \\
\text { approximatio } \\
\mathrm{n} \text { to deal } \\
\text { with } \\
\text { negative } \\
\text { risks and } \\
\text { diversificatio } \\
\mathrm{n}\end{array}$ \\
\hline $\begin{array}{l}\text { Lamb and } \\
\text { Tee (2012b) }\end{array}$ & US & $\begin{array}{l}2000- \\
2004 .\end{array}$ & 30 & $\begin{array}{l}\text { Hedge } \\
\text { funds }\end{array}$ & $\begin{array}{l}\text { Max } \\
(\mathrm{CV} \text { aRo.2, } \\
0) \text { and } \\
\max \\
(\mathrm{SD}, 0) \\
\end{array}$ & $\begin{array}{l}\text { Mean } \\
\text { return, } \\
\max (- \\
\text { CVaR.1, 0). }\end{array}$ & $\begin{array}{l}\text { Input- } \\
\text { orientatio } \\
\mathrm{n}\end{array}$ & $\begin{array}{l}\text { Stochastic } \\
\text { DEA models } \\
\text { using } \\
\text { bootstrap }\end{array}$ \\
\hline $\begin{array}{l}\text { Basso and } \\
\text { Funari } \\
\text { (2014a) }\end{array}$ & EU & $\begin{array}{l}\text { June } \\
2006- \\
\text { June } \\
2009\end{array}$ & 558 & $\begin{array}{l}\text { Mutual } \\
\text { funds, SRI } \\
\text { funds, non- } \\
\text { SRI funds }\end{array}$ & $\begin{array}{l}\text { Coefficien } \\
\mathrm{t} \text { as a risk } \\
\text { measure } \\
\text { of the } \\
\text { investmen } \\
\mathrm{t} \text { in fund, } \\
\text { Initial } \\
\text { payout } \\
\text { invested } \\
\text { in fund }\end{array}$ & $\begin{array}{l}\text { Final value } \\
\text { for fund, } \\
\text { ethical } \\
\text { measure } \\
\text { for fund }\end{array}$ & $\begin{array}{l}\text { Output } \\
\text { orientatio } \\
n\end{array}$ & $\begin{array}{l}\text { Constant and } \\
\text { variable } \\
\text { returns to } \\
\text { scale DEA } \\
\text { models DEA- } \\
\text { CE efficiency } \\
\text { and DEA-VE } \\
\text { efficiency }\end{array}$ \\
\hline $\begin{array}{l}\text { Liu et al. } \\
\text { (2015) }\end{array}$ & China & $\begin{array}{l}\text { January } \\
2008 \text { to } \\
\text { January } \\
2013\end{array}$ & 5 & $\begin{array}{l}\text { Selected } \\
\text { industry } \\
\text { portfolios }\end{array}$ & $\begin{array}{l}\text { Risk } \\
\text { generated } \\
\text { with risk } \\
\text { function }\end{array}$ & $\begin{array}{l}\text { Return } \\
\text { generated } \\
\text { from risk } \\
\text { function }\end{array}$ & $\begin{array}{l}\text { Input and } \\
\text { Output } \\
\text { orientatio } \\
n \text { based }\end{array}$ & $\begin{array}{l}\text { DEA models } \\
\text { under the } \\
\text { mean- } \\
\text { variance }\end{array}$ \\
\hline
\end{tabular}




\begin{tabular}{|c|c|c|c|c|c|c|c|c|}
\hline & & & & & $\begin{array}{l}\text { and } \\
\text { generated } \\
\text { random } \\
\text { weights } \\
\text { for each } \\
\text { portfolio } \\
\text { model } \\
\end{array}$ & $\begin{array}{l}\text { and } \\
\text { generated } \\
\text { random } \\
\text { weights } \\
\text { for each } \\
\text { portfolio } \\
\text { model } \\
\end{array}$ & $\begin{array}{l}\text { on } \\
\text { portfolio } \\
\text { model }\end{array}$ & framework \\
\hline $\begin{array}{l}\text { Brandouy } \\
(2015)\end{array}$ & EU & $\begin{array}{l}\text { October } \\
2005 \text { to } \\
\text { October } \\
2011\end{array}$ & 814 & $\begin{array}{l}\text { Open-end } \\
\text { mutual }\end{array}$ & $\begin{array}{l}\text { Risk as } \\
\text { well as } \\
\text { several } \\
\text { transactio } \\
\text { n costs }\end{array}$ & Return & & $\begin{array}{l}\text { Convex and } \\
\text { non-convex } \\
\text { frontier- } \\
\text { based with } \\
\text { simple back- } \\
\text { testing } \\
\text { analysis }\end{array}$ \\
\hline $\begin{array}{l}\text { Basso and } \\
\text { Funari } \\
(2014 b)\end{array}$ & EU & $\begin{array}{l}\text { June } \\
2006 \text { to } \\
\text { June } \\
2009\end{array}$ & 190 & $\begin{array}{l}\text { SRI Mutual } \\
\text { Funds }\end{array}$ & $\begin{array}{l}\text { DEA-KC } \\
\text { and DEA- } \\
\text { KCE, } \\
\text { DEA-KCE } \\
\text { models: } \\
\text { constant } \\
\text { initial } \\
\text { capital, } \\
\text { standard } \\
\text { deviation } \\
\text { of the } \\
\text { returns }\end{array}$ & $\begin{array}{l}\text { DEA-KC } \\
\text { model: } \\
\text { final } \\
\text { value; } \\
\text { DEA-KCE } \\
\text { and DEA- } \\
\text { KCE: final } \\
\text { value, } \\
\text { ethical } \\
\text { measure }\end{array}$ & $\begin{array}{l}\text { Output } \\
\text { orientatio } \\
\mathrm{n}\end{array}$ & $\begin{array}{l}\text { DEA models; } \\
\text { DEA-KC and } \\
\text { DEA-KCE } \\
\text { and DEA- } \\
\text { KCE model; } \\
\text { focusing on } \\
\text { the main } \\
\text { determinants } \\
\text { of } \\
\text { investments } \\
\text { in SRI }\end{array}$ \\
\hline $\begin{array}{l}\text { Branda } \\
(2015)\end{array}$ & US & $\begin{array}{l}\text { January } \\
2002 \text { to } \\
\text { Decemb } \\
\text { er } 2011\end{array}$ & 48 & $\begin{array}{l}\text { Selected } \\
\text { industry } \\
\text { portfolios }\end{array}$ & $\begin{array}{l}\text { Coherent } \\
\text { risk }\end{array}$ & $\begin{array}{l}\text { Coherent } \\
\text { return }\end{array}$ & N/A & $\begin{array}{l}\text { Diversificatio } \\
\mathrm{n} \text {-consistent } \\
\text { (DC) DEA }\end{array}$ \\
\hline $\begin{array}{l}\text { Branda } \\
(2016)\end{array}$ & US & $\begin{array}{l}\text { July } \\
2004 \\
\text { June } \\
2014\end{array}$ & 48 & $\begin{array}{l}\text { Selected } \\
\text { industry } \\
\text { portfolios }\end{array}$ & $\begin{array}{l}\text { Value at } \\
\text { risk on } \\
\text { several } \\
\text { levels }\end{array}$ & Return & & $\begin{array}{l}\text { Diversificatio } \\
\text { n-consistent } \\
\text { (DC) DEA } \\
\text { based on } \\
\text { directional } \\
\text { distance }\end{array}$ \\
\hline
\end{tabular}

The various papers on the money market funds main path focus only on mutual funds. Basso and

Funari make the biggest contribution to the papers on the main path (4 out of 10 papers). The largest number of observations $(2,083)$ is for the paper by Murthi et al. (1997), which studies the DPEI of US mutual fund for one quarter of 1993.

Table 6 shows that the most recent studies develop novel indices using DEA to measure the efficiency of mutual funds. 


\subsection{Insurance main path}

Figure 5 depicts the main route for insurance papers. There is a main path ending in two one-node streams, and consists of nine papers. The first three articles on the insurance path have the same first author. The first paper, Cummins2004 (Cummins et al. 2004), tests hypotheses on the effects of organizational structures on the efficiency of Spanish stock and mutual insurers, over the period 1989-1997, employing input-oriented distance functions. The second paper, Cummins2006 (Cummins and Rubio-Misas 2006), investigates the impact of deregulation and consolidation on Spanish insurance industry costs, technical and allocative efficiency over 1989-1998, and changes to TFP. The third paper, Cummins2008 (Cummins and Xie 2008), studies the effect of mergers and acquisitions on the efficiency of the US property-liability ${ }^{3}$ insurance industry, during the period 1994-2003, employing a value-added approach to specify inputs and outputs.

Eling2010 (Eling and Luhnen 2010) analyses the efficiency of a broad international dataset consisting of 6,462 insurance companies in 36 countries, over 2002-2006. To measure technical and cost efficiency, the authors apply both DEA and SFA. Cummins et al. 2010 (Cummins2010) adopt two-stage DEA to investigate the efficiency of US insurance companies during the period 19932006, and examine the efficiency levels of insurance companies offering both life-health and property-liability services, and those offering these services separately.

After Xie2011 (Xie et al. 2011), the main path divides into two streams. Xie et al. provide technical and cost efficiencies for 37 US life insurance firms experiencing demutualization and examine whether converting firms experience post-demutualization efficiency improvements. The right stream, which originates from Xie2011, includes Barros2014 (Barros and Wanke 2014), which

\footnotetext{
${ }^{3}$ Property-liability insurance pricing was proposed in 1926 to integrate underwriting and investment performance. A description of the development of property-liability insurance pricing models can be found in Cooper (1974) and D'Arcy and Doherty (1988).
} 
estimates the efficiency of Mozambique insurance companies by applying bootstrapping to classical BCC and CCR. In order to identify the major input and output slacks and predict them against the contextual variables, principal component analysis and neural network analysis are applied. In the left-hand stream, Barros2014 (Barros et al. 2014) studies the performance of Angolan insurance companies between 2003 and 2012. The right and left streams merge in Wanke2016 (Wanke \& Barros 2016). Wanke and Barros employ a two-stage DEA to investigate the role of heterogeneity in the insurance sector. In the first stage they use DEA meta-frontier and, in the second stage, they use a number of data mining techniques. They apply the model to a balanced panel data set of Brazilian insurance companies and show that there is a heterogeneous impact on the efficiency levels of geographical regions and insurance types of insurance companies.

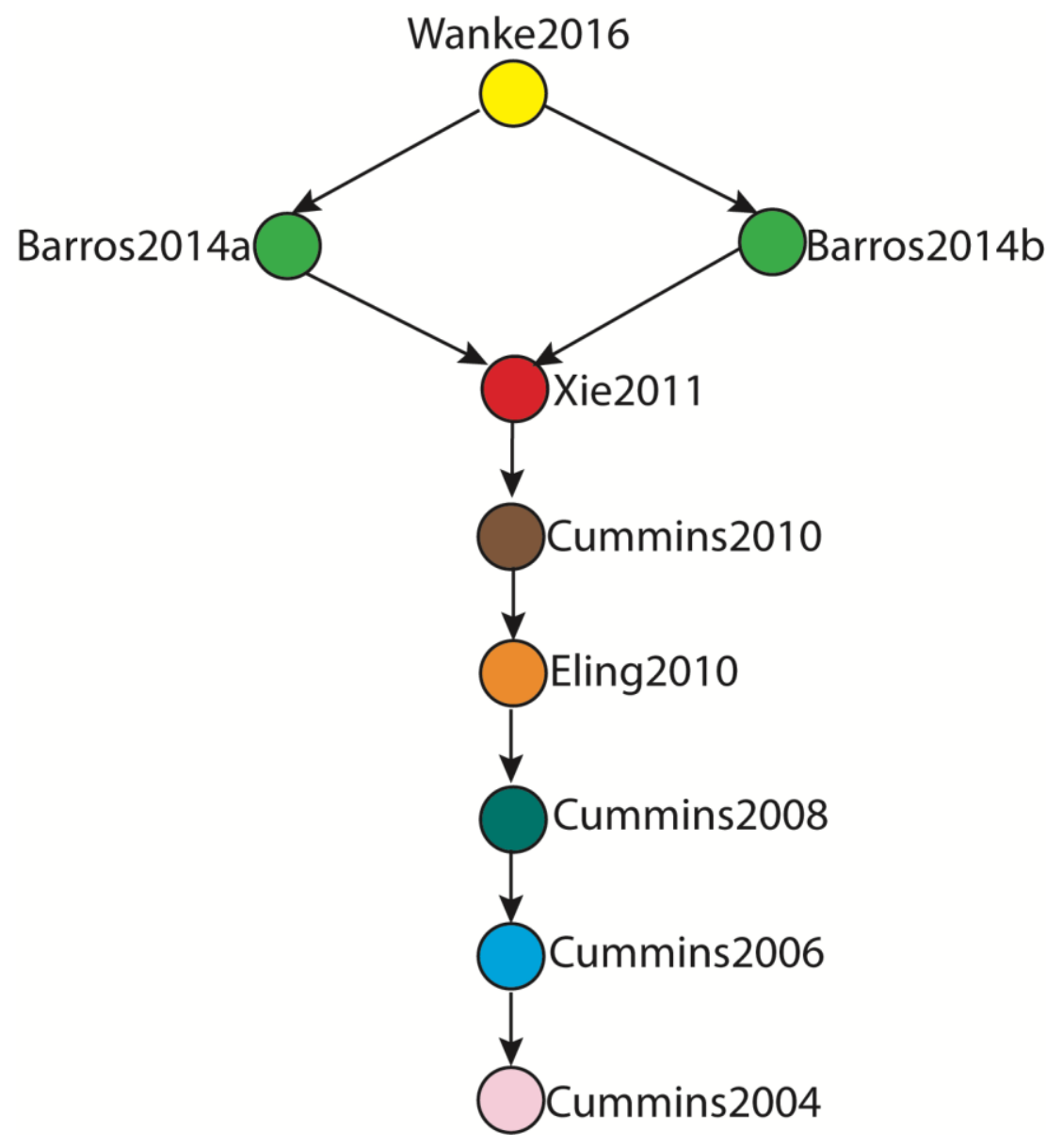


Figure 5. Insurance main path

Table 7. Analysis of papers on the main path of insurance group

\begin{tabular}{|c|c|c|c|c|c|c|c|c|}
\hline \multirow{2}{*}{$\begin{array}{l}\text { Resea } \\
\text { rch }\end{array}$} & \multicolumn{4}{|c|}{ Evaluated DMUs } & \multicolumn{2}{|c|}{ Input and Outputs } & \multirow[b]{2}{*}{$\begin{array}{l}\text { Environment } \\
\text { al variable }\end{array}$} & \multirow[b]{2}{*}{$\begin{array}{l}\text { Efficienc } \\
\text { y type }\end{array}$} \\
\hline & $\begin{array}{l}\text { Geograp } \\
\text { hical } \\
\text { region }\end{array}$ & $\begin{array}{l}\text { Period } \\
\text { of } \\
\text { study }\end{array}$ & Quantity & $\begin{array}{l}\text { Type of } \\
\text { Insurer }\end{array}$ & Input & Output & & \\
\hline $\begin{array}{l}\text { Cumm } \\
\text { ins et } \\
\text { al. } \\
(2004)\end{array}$ & Spain & $\begin{array}{l}1989- \\
1997\end{array}$ & 3121 & $\begin{array}{l}\text { Stock } \\
\text { and } \\
\text { mutual } \\
\text { insurers }\end{array}$ & $\begin{array}{l}\text { Labour, } \\
\text { business, } \\
\text { financial } \\
\text { debt } \\
\text { capital, } \\
\text { equity } \\
\text { capital }\end{array}$ & $\begin{array}{l}\text { Life and } \\
\text { non-life } \\
\text { insurance } \\
\text { losses } \\
\text { incurred }\end{array}$ & $\begin{array}{l}\text { Organizatio } \\
\text { nal structure }\end{array}$ & $\begin{array}{l}\text { Technica } \\
1, \text { cost, } \\
\text { and } \\
\text { revenue } \\
\text { efficienc } \\
\text { y }\end{array}$ \\
\hline $\begin{array}{l}\text { Cumm } \\
\text { ins and } \\
\text { Rubio } \\
(2006)\end{array}$ & Spain & $\begin{array}{l}1989- \\
1998\end{array}$ & 3831 & Insurers & $\begin{array}{l}\text { Labour, } \\
\text { business } \\
\text { services, } \\
\text { debt } \\
\text { capital, } \\
\text { equity } \\
\text { capital }\end{array}$ & $\begin{array}{l}\text { Life and } \\
\text { non-life } \\
\text { insurance } \\
\text { losses } \\
\text { incurred, } \\
\text { reinsuranc } \\
\text { e reserves, } \\
\text { reserves } \\
\text { for } \\
\text { primary } \\
\text { insurance } \\
\text { contracts, } \\
\text { invested } \\
\text { assets }\end{array}$ & $\begin{array}{l}\text { Deregulatio } \\
\mathrm{n}, \\
\text { consolidatio } \\
\mathrm{n}\end{array}$ & $\begin{array}{l}\text { Cost, } \\
\text { technical, } \\
\text { allocative } \\
\text { efficienc } \\
\text { y }\end{array}$ \\
\hline $\begin{array}{l}\text { Cumm } \\
\text { ins and } \\
\text { Xie } \\
(2008)\end{array}$ & US & $\begin{array}{l}1993- \\
2003\end{array}$ & $\begin{array}{l}\text { Acquiring firms: } 150 \text {; non- } \\
\text { acquiring firms } 6255 \text { target } \\
\text { firms: } 241 \text {; non-target } \\
\text { firms: } 8694\end{array}$ & $\begin{array}{l}\text { property- } \\
\text { liability } \\
\text { insurer }\end{array}$ & $\begin{array}{l}\text { Administr } \\
\text { ative } \\
\text { labour, } \\
\text { agent } \\
\text { labour, } \\
\text { materials, } \\
\text { business } \\
\text { services, } \\
\text { financial } \\
\text { equity } \\
\text { capital }\end{array}$ & $\begin{array}{l}\text { Personal } \\
\text { lines short } \\
\text { and long- } \\
\text { tail } \\
\text { coverages, } \\
\text { commerci } \\
\text { al lines } \\
\text { short and } \\
\text { long tail } \\
\text { coverages, }\end{array}$ & $\begin{array}{l}\text { Mergers \& } \\
\text { acquisitions }\end{array}$ & $\begin{array}{l}\text { Cost, } \\
\text { technical, } \\
\text { allocative } \\
\text {, pure } \\
\text { technical, } \\
\text { scale, } \\
\text { revenue } \\
\text { efficienc } \\
\text { y- } \\
\text { Malmqui } \\
\text { st } \\
\text { indexes }\end{array}$ \\
\hline $\begin{array}{l}\text { Eling } \\
\text { and } \\
\text { Lugne } \\
\mathrm{n} \\
(2010)\end{array}$ & $\begin{array}{l}36 \\
\text { countries }\end{array}$ & $\begin{array}{l}2002- \\
2006\end{array}$ & 26,505 & $\begin{array}{l}\text { Life and } \\
\text { non-life } \\
\text { insuranc } \\
\text { e insurer }\end{array}$ & $\begin{array}{l}\text { Labour } \\
\text { and } \\
\text { business, } \\
\text { debt } \\
\text { capital, } \\
\text { equity } \\
\text { capital; } \\
\text { service, }\end{array}$ & $\begin{array}{l}\text { Non-life } \\
\text { claims + } \\
\text { additions, } \\
\text { life } \\
\text { benefits + } \\
\text { additions } \\
\text { to } \\
\text { reserves, } \\
\text { investmen } \\
\text { ts } \\
\text { to } \\
\text { reserves, }\end{array}$ & N/A & $\begin{array}{l}\text { Technica } \\
1, \text { cost } \\
\text { efficienc } \\
y\end{array}$ \\
\hline $\begin{array}{l}\text { Cumm } \\
\text { ins et } \\
\text { al. } \\
(2010)\end{array}$ & US & $\begin{array}{l}1993- \\
2006\end{array}$ & $\begin{array}{l}\text { Life health: } 3160 \text {; Popper- } \\
\text { liability: } 8635\end{array}$ & $\begin{array}{l}\text { life- } \\
\text { health } \\
\text { and } \\
\text { property- } \\
\text { liability }\end{array}$ & $\begin{array}{l}\text { Home } \\
\text { office } \\
\text { labour, } \\
\text { agent } \\
\text { labour, } \\
\text { business } \\
\text { services, } \\
\text { equity } \\
\text { capital }\end{array}$ & $\begin{array}{l}\text { Individual } \\
\text { life, } \\
\text { individual } \\
\text { annuities, } \\
\text { group life, } \\
\text { group } \\
\text { annuities, } \\
\text { accident } \\
\text { and } \\
\text { health, } \\
\text { intermedia } \\
\text { tion }\end{array}$ & N/A & $\begin{array}{l}\text { Technica } \\
\text { l, pure } \\
\text { technical, } \\
\text { cost, } \\
\text { scale, } \\
\text { revenue, } \\
\text { allocative } \\
\text { efficienc } \\
\text { y, profit } \\
\text { inefficien } \\
\text { cy }\end{array}$ \\
\hline
\end{tabular}




\begin{tabular}{|c|c|c|c|c|c|c|c|c|}
\hline $\begin{array}{l}\text { Xie et } \\
\text { al. } \\
\text { (2011) }\end{array}$ & US & $\begin{array}{l}1993- \\
2003\end{array}$ & & $\begin{array}{l}\text { Life } \\
\text { insurer }\end{array}$ & $\begin{array}{l}\text { Administr } \\
\text { ative } \\
\text { labour, } \\
\text { agent } \\
\text { labour, } \\
\text { materials, } \\
\text { business } \\
\text { services, } \\
\text { financial } \\
\text { equity } \\
\text { capital. }\end{array}$ & $\begin{array}{l}\text { Individual } \\
\text { life } \\
\text { insurance, } \\
\text { Individual } \\
\text { annuities, } \\
\text { group life } \\
\text { insurance, } \\
\text { group } \\
\text { annuities } \\
\text { and } \\
\text { accident } \\
\text { and health } \\
\text { insurance, } \\
\text { one } \\
\text { intermedia } \\
\text { ry output } \\
\text { (invested } \\
\text { assets) is } \\
\text { defined } \\
\text { for } \\
\text { financial } \\
\text { intermedia } \\
\text { tion } \\
\text { services } \\
\text { provided } \\
\text { by } \\
\text { insurance } \\
\text { companies }\end{array}$ & $\begin{array}{l}\text { Demutualiz } \\
\text { ation, } \\
\text { control }\end{array}$ & $\begin{array}{l}\text { Cost, } \\
\text { technical } \\
\text { efficienc } \\
\mathrm{y}\end{array}$ \\
\hline $\begin{array}{l}\text { Barros } \\
\text { and } \\
\text { Wanke } \\
\text { (2014) }\end{array}$ & $\begin{array}{l}\text { Mozambi } \\
\text { que }\end{array}$ & $\begin{array}{l}2002- \\
2011\end{array}$ & N/A & N/A & $\begin{array}{l}\text { Operating } \\
\text { costs, } \\
\text { number of } \\
\text { employees } \\
\text {, wages, } \\
\text { capital }\end{array}$ & $\begin{array}{l}\text { Claims } \\
\text { paid, } \\
\text { profits } \\
\text { paid, } \\
\text { premiums } \\
\text { earned, } \\
\text { ceded } \\
\text { reinsuranc } \\
\text { e }\end{array}$ & N/A & $\begin{array}{l}\text { Technica } \\
1 \text {, } \\
\text { bootstrap } \\
\text { ped } \\
\text { efficienc } \\
\text { y }\end{array}$ \\
\hline $\begin{array}{l}\text { Barros } \\
\text { et al. } \\
\text { (2014) }\end{array}$ & Angola & $\begin{array}{l}2003- \\
2012\end{array}$ & & $\begin{array}{l}\text { Life and } \\
\text { non-life } \\
\text { Insurer }\end{array}$ & $\begin{array}{l}\text { Operating } \\
\text { costs, } \\
\text { number of } \\
\text { employees } \\
\text {, wages, } \\
\text { capital }\end{array}$ & $\begin{array}{l}\text { Claims } \\
\text { paid, } \\
\text { profits } \\
\text { paid } \\
\text { premiums } \\
\text { earned, } \\
\text { ceded } \\
\text { reinsuranc } \\
\text { e }\end{array}$ & N/A & $\begin{array}{l}\text { Technica } \\
1, \\
\text { bootstrap } \\
\text { ped } \\
\text { efficienc } \\
\text { y }\end{array}$ \\
\hline $\begin{array}{l}\text { Wank } \\
\text { e and } \\
\text { Barros } \\
\text { (2016) }\end{array}$ & Brazil & $\begin{array}{l}1995- \\
2013\end{array}$ & $\begin{array}{l}\text { Wanke and Barros } \\
\text { (2016) }\end{array}$ & Brazil & $\begin{array}{l}1995- \\
2013\end{array}$ & $\begin{array}{l}\text { Wanke } \\
\text { and } \\
\text { Barros } \\
(2016)\end{array}$ & Brazil & $\begin{array}{l}1995- \\
2013\end{array}$ \\
\hline
\end{tabular}

Table 7 presents the geographical distribution of insurance group papers. US, Taiwan and China have the largest number of papers on the application of DEA in the insurance industry. DEA has been applied in several multi-country studies of the BRIC, Islamic and EU countries. 
Most papers on the insurance main path focus on the efficiency of life and non-life, propertyliability insurers. The largest data sample is in the study by Eling and Lugnen (2010), which examines the efficiency of life and non-life insurance companies in over 36 countries. Three out of eight papers on the path focus on US data, which shows the importance of these studies in the literature. Comparing Tables (7) and (5) shows that very few sophisticated DEA techniques have been applied to measure the efficiency of insurance companies.

\section{Conclusions}

DEA research in financial services studies has increased in recent years. The resulting large DEA literature makes it difficult to conduct a general review without resorting to quantitative methodologies.

The availability of data in this field from databases, such as Bank-Scope, especially in the banking domain, has resulted in these data being used to experiment with the newly developed DEA models. In this paper, we surveyed DEA applications in the context of financial services using a quantitative and citations network approach. We identified significant paths, important papers, and innovative methodologies related to the application of DEA in financial services. We identified three main areas of application within the financial services sector - the banking industry, the insurance industry and money market funds. We considered 596 articles from the year 1985 onwards, which, in our view, provides a thorough mapping of the field.

We highlighted the main flow of ideas characterizing analyses of efficiency using DEA. Our examination of individual main routes suggests that there are no obvious methodological preferences for any of the corresponding three areas. Recent innovations in DEA methodologies (network models, slacks based models, directional distance models and Nash bargaining game) clearly dominate the ends of the routes on the main paths. Geographical analysis of the papers in 
our sample showed that banking systems are the most frequently studied systems - especially for the US, China, Taiwan, Latin-America, Japan and the Arab countries.

This study has some limitations. The sample was taken from the ISI WoS, which is recognized as the largest citation-based academic database. However, some works dealing with DEA and financial services may not be included in the WoS, which means this study is less comprehensive than ideal.

\section{Acknowledgements}

The authors would like to thank the three anonymous referees for their useful insights which have helped improve the argument in this paper.

\section{References}

Athanassopoulos, A. D. (1998). Non-parametric frontier models for assessing the market and cost efficiency of large scale bank branch networks. Journal of Money Credit and Banking, 30(2), 172192. http://papers.ssrn.com/abstract=50740. Accessed 11 December 2015

Avkiran, N. (2009). Opening the black box of efficiency analysis: An illustration with UAE banks. Omega, 37(4), 930-941. doi:10.1016/j.omega.2008.08.001

Avkiran, N. K. (1999). The evidence on efficiency gains: The role of mergers and the benefits to the public. Journal of Banking \& Finance, 23(7), 991-1013. doi:http://dx.doi.org/10.1016/S03784266(98)00129-0

Avkiran, N. K. (2011). Association of DEA super-efficiency estimates with financial ratios: Investigating the case for Chinese banks. Omega, 39(3), 323-334. doi:10.1016/j.omega.2010.08.001

Avkiran, N. K. (2015). An illustration of dynamic network DEA in commercial banking including robustness tests. Omega, 55, 141-150. doi:10.1016/j.omega.2014.07.002

Avkiran, N. K., \& Alpert, K. (2015). The influence of co-authorship on article impact in OR/MS/OM and the exchange of knowledge with Finance in the twenty-first century. Annals of Operations Research, 235(1), 51-73. doi:10.1007/s10479-015-1880-y

Avkiran, N. K., \& Morita, H. (2010). Benchmarking firm performance from a multiple-stakeholder perspective with an application to Chinese banking. Omega, 38(6), 501-508. doi:10.1016/j.omega.2009.12.007

Banker, R. D., Charnes, A., \& Cooper, W. W. (1984). Some models for estimating technical and scale inefficiencies in data envelopment analysis. Management Science, 30(9), 1078-1092. 
doi:10.1287/mnsc.30.9.1078

Barberá-Tomás, D., Jiménez-Sáez, F., \& Castelló-Molina, I. (2011). Mapping the importance of the real world: The validity of connectivity analysis of patent citations networks. Research Policy, 40(3), 473-486.

Barros, C. P., Dumbo, S., \& Wanke, P. (2014). Efficiency determinants and capacity issues in Angolan insurance companies. South African Journal of Economics, 82(3), 455-467. doi:10.1111/saje.12056

Barros, C. P., Managi, S., \& Matousek, R. (2012). The technical efficiency of the Japanese banks: Non-radial directional performance measurement with undesirable output. Omega, 40(1), 1-8. doi:10.1016/j.omega.2011.02.005

Barros, C. P., \& Wanke, P. (2014). Insurance companies in Mozambique: a two-stage DEA and neural networks on efficiency and capacity slacks. Applied Economics. http://www.tandfonline.com/doi/abs/10.1080/00036846.2014.934436. Accessed 5 June 2015

Basso, A., \& Funari, S. (2001). A data envelopment analysis approach to measure the mutual fund performance. European Journal of Operational Research, 135(3), 477-492. doi:10.1016/S03772217(00)00311-8

Basso, A., \& Funari, S. (2003). Measuring the performance of ethical mutual funds: a DEA approach. Journal of the Operational Research Society, 54(5), 521-531. doi:10.1057/palgrave.jors.2601541

Basso, A., \& Funari, S. (2014). Constant and variable returns to scale DEA models for socially responsible investment funds. European Journal of Operational Research, 235(3), 775-783. doi:10.1016/j.ejor.2013.11.024

Batagelj, V. (2003). Efficient algorithms for citation network analysis. Institute of Mathematics, 1-29. http://arxiv.org/abs/cs/0309023. Accessed 11 March 2013

Bekkers, R., \& Martinelli, A. (2012). Knowledge positions in high-tech markets: Trajectories, standards, strategies and true innovators. Technological Forecasting and Social Change, 79(7), 1192-1216.

Berg, S. A., Førsund, F. R., Hjalmarsson, L., \& Suominen, M. (1993). Banking efficiency in the Nordic countries. Journal of Banking \& Finance, 17(2-3), 371-388. doi:http://dx.doi.org/10.1016/0378-4266(93)90038-F

Berg, S. A., Førsund, F. R., \& Jansen, E. S. (1992). Malmquist Indices of Productivity Growth during the Deregulation of Norwegian Banking, 1980-89. Scandinavian Journal of Economics, 94, S21128. http://econpapers.repec.org/RePEc:bla:scandj:v:94:y:1992:i:0:p:s211-28. Accessed 3 June 2015

Berger, Allen N, William C Hunter, and Stephen G Timme. 1993. “The Efficiency of Financial Institutions: A Review and Preview of Research Past, Present and Future." Journal of Banking \& Finance 17 (2-3): 221-249. doi:http://dx.doi.org/10.1016/0378-4266(93)90030-H.

Berger, Allen N., and David B. Humphrey. 1997. “Efficiency of Financial Institutions: International Survey and Directions for Future Research." European Journal of Operational Research 98 (2): 175-212. doi:10.1016/S0377-2217(96)00342-6.

Bhupatiraju, S., Nomaler, Ö., Triulzi, G., \& Verspagen, B. (2012). Knowledge flows - Analyzing the core literature of innovation, entrepreneurship and science and technology studies. Research Policy, 41(7), 1205-1218. 
Branda, M. (2015). Diversification-consistent data envelopment analysis based on directionaldistance measures. Omega, 52, 65-76.

Branda, M. (2016). Mean-value at risk portfolio efficiency: approaches based on data envelopment analysis models with negative data and their empirical behaviour. 4OR, 14(1), 77-99. doi:10.1007/s10288-015-0296-5

Brandouy, O., Kerstens, K., \& Van de Woestyne, I. (2015). Frontier-based vs. traditional mutual fund ratings: A first backtesting analysis. European Journal of Operational Research, 242(1), 332342. doi:10.1016/j.ejor.2014.11.010

Breschi, S., \& Lissoni, F. (2003). Knowledge-relatedness in firm technological diversification. Research Policy, 32(January 2001), 69-87.

Camanho, A. S., Dyson, R. G., The, I., \& Sim, T. (1999). Efficiency, size, benchmarks and targets for bank branches: an application of data envelopment analysis. Journal of the Operational Research Society, 50(9), 903-915. doi:10.1057/palgrave.jors.2600792

Charnes, A., Cooper, W. W., \& Rhodes, E. (1978). Measuring the efficiency of decision making units. European Journal of Operational Research, 2(6), 429-444. doi:10.1016/0377-2217(78)90138-8

Cook, W. D., \& Seiford, L. M. (2009). Data envelopment analysis (DEA) - Thirty years on. European Journal of Operational Research, 192(1), 1-17. doi:10.1016/j.ejor.2008.01.032

Cooper, R. W. (1974). Investment return and property-liability insurance ratemaking. Philadelphia: SS Huebner Foundation, University of Pennsylvania.

Cooper, W. W., Seiford, L. M., Tone, K., \& Zhu, J. (2007). Some models and measures for evaluating performances with DEA: past accomplishments and future prospects. Journal of Productivity Analysis, 28(3), 151-163. doi:10.1007/s11123-007-0056-4

Cummins, J. D., \& Rubio-Misas, M. (2006). Deregulation, consolidation, and efficiency: Evidence from the Spanish insurance industry. Journal of Money Credit and Banking, 38(2), 323-355. doi:DOI 10.1353/mcb.2006.0029

Cummins, J. D., Rubio-Misas, M., \& Zi, H. (2004). The effect of organizational structure on efficiency: Evidence from the Spanish insurance industry. Journal of Banking $\mathcal{E}$ Finance, 28(12), 3113-3150. doi:http://dx.doi.org/10.1016/j.jbankfin.2004.05.004

Cummins, J. D., \& Xie, X. (2008). Mergers and acquisitions in the US property-liability insurance industry: Productivity and efficiency effects. Journal of Banking $\mathcal{E}$ Finance, 32(1), 30-55. doi:http://dx.doi.org/10.1016/j.jbankfin.2007.09.003

D'Arcy, S. P., \& Doherty, N. A. (1988). The Financial Theory of Pricing Property-liability Insurance Contracts, Volumes 11-15. S.S. Huebner Foundation for Insurance Education.

Ding, Y., Liu, X., Guo, C., \& Cronin, B. (2013). The distribution of references across texts: Some implications for citation analysis. Journal of Informetrics, 7(3), 583-592. http://dx.doi.org/10.1016/j.joi.2013.03.003. Accessed 21 April 2013

Eling, M., \& Luhnen, M. (2010). Efficiency in the international insurance industry: A cross-country comparison. Journal of Banking \& Finance, 34(7), 1497-1509. doi:http://dx.doi.org/10.1016/j.jbankfin.2009.08.026

Elyasiani, E., \& Mehdian, S. M. (1990). A nonparametric approach to measurement of efficiency and technological change: The case of large U.S. commercial banks. Journal of Financial Services Research, 4(2), 157-168. doi:10.1007/BF00352569 
Emrouznejad, A., \& Marra, M. (2014). Ordered Weighted Averaging Operators 1988-2014: A Citation-Based Literature Survey. International Journal of Intelligent Systems, n/a-n/a.

Emrouznejad, A., Parker, B. R., \& Tavares, G. (2008). Evaluation of research in efficiency and productivity: A survey and analysis of the first 30 years of scholarly literature in DEA. SocioEconomic Planning Sciences, 42(3), 151-157. doi:10.1016/j.seps.2007.07.002

Epicoco, M. (2013). Knowledge patterns and sources of leadership: Mapping the semiconductor miniaturization trajectory. Research Policy, 42(1), 180-195.

Fan, D., Lo, C. K. Y., Ching, V., \& Kan, C. W. (2014). Occupational health and safety issues in operations management: A systematic and citation network analysis review. International Journal of Production Economics, 158, 334-344. doi:10.1016/j.ijpe.2014.07.025

Favero, C. A., \& Papi, L. (1995). Technical efficiency and scale efficiency in the Italian banking sector: a non-parametric approach. Applied Economics, 27(4), 385-395. doi:10.1080/00036849500000123.

Farrell, M. J. (1957). The measurement of productive efficiency. Journal of the Royal Statistical Society. Series A (General), 120(3), 253-290. doi:10.1016/S0377-2217(01)00022-4

Fethi, M. D., \& Pasiouras, F. (2010). Assessing bank performance with operational artificial intelligence techniques: A Survey. European Journal of Operational Research, 204(2), 189-198.

Fontana, R., Nuvolari, A., \& Verspagen, B. (2009). Mapping technological trajectories as patent citation networks: An application to data communication standards. Economics of Innovation and New Technologies, 18(4), 311-336.

Garfield, E. (2009). From the science of science to Scientometrics visualizing the history of science with HistCite software. Journal of Informetrics, 1, 21-26.

Garfield, E., Sher, I., \& Torpie, R. (1964). The Use of Citation Data in Writing the History of Science. (Institute for Scientific Information, Ed.)Institute for Scientific Information. Philadelphia: Institute for Scientific Information.

Gattoufi, S., Oral, M., \& Reisman, A. (2004). Data envelopment analysis literature: A bibliography update (1951-2001). Journal of Socio-Economic Planning Science, 38(2-3), 159-229.

Giokas, D. (1991). Bank branch operating efficiency: A comparative application of DEA and the loglinear model. Omega, 19(6), 549-557. doi:10.1016/0305-0483(91)90005-E

Giokas, D. I. (2008). Assessing the efficiency in operations of a large Greek bank branch network adopting different economic behaviors. Economic Modelling, 25(3), 559-574. doi:10.1016/j.econmod.2007.10.007

Glawischnig, M., \& Sommersguter-Reichmann, M. (2010). Assessing the performance of alternative investments using non-parametric efficiency measurement approaches: Is it convincing? Journal of Banking E Finance, 34(2), 295-303. doi:10.1016/j.jbankfin.2009.07.017

Golany, B., \& Storbeck, J. (1999). A data envelopment analysis of the operational efficiency of bank branches. Interfaces, 29(3), 14-26.

Gonzalez, M., \& Trujillo, L. (2009). Efficiency measurement in the port industry: a survey of the empirical evidence. Journal of Transport Economic and Policy, 43(2), 157-192. http://ideas.repec.org/p/cty/dpaper/07-08.html. Accessed 3 June 2015

Grosskopf, S. (1996). Statistical inference and nonparametric efficiency: A selective survey. Journal of Productivity Analysis, 7(2-3), 161-176. doi:10.1007/BF00157039 
Hauner, D. (2008). Credit to government and banking sector performance. Journal of Banking $\mathcal{E}$ Finance, 32(8), 1499-1507. doi:http://dx.doi.org/10.1016/j.jbankfin.2007.07.012

Herrera-Restrepo, O., Triantis, K., Seaver, W. L., Paradi, J. C., \& Zhu, H. (2016). Bank branch operational performance: A robust multivariate and clustering approach. Expert Systems with Applications, 50, 107-119. doi:10.1016/j.eswa.2015.12.025

Hollingsworth, B. (2003). Non-parametric and parametric applications measuring efficiency in health care. Health Care Management Science, 6(4), 203-218. doi:10.1023/A:1026255523228

Hollingsworth, B., Dawson, P. J., \& Maniadakis, N. (1999). Efficiency measurement of health care: a review of non-parametric methods and applications. Health Care Management Science, 2(3), 161-172. doi:10.1023/A:1019087828488

Hummon, N. P., \& Doreian, P. (1989). Connectivity in a citation network: The development of the DNA theory. Social Networks, 11, 39-63. doi:10.1016/0378-8733(89)90017-8

Jensen, M. C. (1968). The performance of mutual funds in the period 1945-1964. The Journal of Finance, 23(2), 389-416. doi:10.1111/j.1540-6261.1968.tb00815.x

Joro, T., \& Na, P. (2006). Portfolio performance evaluation in a mean-variance-skewness framework. European Journal of Operational Research, 175(1), 446-461. doi:10.1016/j.ejor.2005.05.006

Juo, J.-C., Fu, T.-T., \& Yu, M.-M. (2012). Non-oriented slack-based decompositions of profit change with an application to Taiwanese banking. Omega, 40(5), 550-561.

doi:10.1016/j.omega.2011.11.002

Kao, C., \& Liu, S.-T. (2014). Multi-period efficiency measurement in data envelopment analysis: The case of Taiwanese commercial banks. Omega, 47, 90-98. doi:10.1016/j.omega.2013.09.001

Kejžar, N., Černe, S. K., \& Batagelj, V. (2010). Network analysis of works on clustering and classification from Web of Science. In H. Locarek-Junge \& C. Weihs (Eds.), Classification as a Tool for Research (pp. 525-536). Berlin, Heidelberg: Springer Berlin Heidelberg. http://www.springerlink.com/index/10.1007/978-3-642-10745-0. Accessed 15 November 2013

Kerstens, K., Mounir, A., \& de Woestyne, I. Van. (2011). Non-parametric frontier estimates of mutual fund performance using C- and L-moments: Some specification tests. Journal of Banking E Finance, 35(5), 1190-1201. doi:http://dx.doi.org/10.1016/j.jbankfin.2010.09.030

Kirkwood, J., \& Nahm, D. (2006). Australian Banking Efficiency and Its Relation to Stock Returns. Economic Record, 82(258), 253-267. doi:10.1111/j.1475-4932.2006.00338.x

Lamb, John D. Tee, Kai-Hong 2012a. Resampling DEA estimates of investment fund performance, European Journal of Operational Research, 223(3), 834-841.

Lamb, John D. Tee, Kai-Hong 2012b. Data envelopment analysis models of investment funds. European Journal of Operational Research, 216(3), 687-696.

Lampe, H. W., \& Hilgers, D. (2014). Trajectories of efficiency measurement: A bibliometric analysis of DEA and SFA. European Journal of Operational Research, 240(1), 1-21.

doi:10.1016/j.ejor.2014.04.041

Lampe, H. W., \& Hilgers, D. (2015). Trajectories of efficiency measurement: A bibliometric analysis of DEA and SFA. European Journal of Operational Research, 240(1), 1-21.

doi:10.1016/j.ejor.2014.04.041

Liu, J., Lu, L. Y. Y., Lu, W. M., \& Lin, B. J. Y. (2013). A survey of DEA applications. Omega, 41(5), 
893-902.

Liu, J. S., Lu, L. Y. Y., \& Lu, W.-M. (2016). Research fronts in data envelopment analysis. Omega, 58, $33-45$.

Liu, J. S., Lu, L. Y. Y., Lu, W.-M., \& Lin, B. J. Y. (2013). Data envelopment analysis 1978-2010: A citation-based literature survey. Omega, 41(1), 3-15. doi:10.1016/j.omega.2010.12.006

Liu, W., Zhou, Z., Liu, D., \& Xiao, H. (2015). Estimation of portfolio efficiency via DEA. Omega, 52, 107-118. doi:10.1016/j.omega.2014.11.006

Lozano, S., \& Gutiérrez, E. (2008). Data envelopment analysis of mutual funds based on secondorder stochastic dominance. European Journal of Operational Research, 189(1), 230-244.

Lucio-Arias, D., \& Leydesdorf, L. (2008). Main-path analysis and path-dependent transitions in HistCite TM -based historiograms. Journal of the American Society for Information Science and Technology, 59(12), 1948-1962.

Martinelli, A. (2012). An emerging paradigm or just another trajectory? Understanding the nature of technological changes using engineering heuristics in the telecommunications switching industry. Research Policy, 41(2), 414-429. doi:10.1016/j.respol.2011.10.012

Mina, A., Ramlogan, R., Tampubolon, G., \& Metcalfe, J. S. (2007). Mapping evolutionary trajectories: Applications to the growth and transformation of medical knowledge. Research Policy, 36(5), 789-806. doi:10.1016/j.respol.2006.12.007

Murthi, B. P. S., Choi, Y. K., \& Desai, P. (1997). Efficiency of mutual funds and portfolio performance measurement: A non-parametric approach. European Journal of Operational Research, 98(2), 408-418. doi:10.1016/S0377-2217(96)00356-6

Nerur, S. P., Rasheed, A. A., \& Natarajan, V. (2008). The intellectual structure of the strategic management field: an author co-citation analysis. Strategic Management Journal, 29(3), 319-336. doi:10.1002/smj.659

Nooy, W. de, Mrvar, A., \& Batagelj, V. (2005). Exploratory Social Network Analysis with Pajek. Cambridge University Press.

Oum, T. H., Waters, W., \& Yu, C. (1999). A survey of productivity and efficiency measurement in rail transport. Journal of Transport Economic and Policy, 33(1), 9-42.

Paradi, J. C., Rouatt, S., \& Zhu, H. (2011). Two-stage evaluation of bank branch efficiency using data envelopment analysis. Omega, 39(1), 99-109. doi:10.1016/j.omega.2010.04.002

Paradi, J. C., \& Schaffnit, C. (2004). Commercial branch performance evaluation and results communication in a Canadian bank-a DEA application. European Journal of Operational Research, 156(3), 719-735. doi:10.1016/S0377-2217(03)00108-5

Paradi, J. C., \& Zhu, H. (2013). A survey on bank branch efficiency and performance research with data envelopment analysis. Omega, 41(1), 61-79. doi:10.1016/j.omega.2011.08.010

Portela, M. C. a S., \& Thanassoulis, E. (2005). Profitability of a sample of Portuguese bank branches and its decomposition into technical and allocative components. European Journal of Operational Research, 162(3), 850-866. doi:10.1016/j.ejor.2003.10.018

Portela, M. C. a S., \& Thanassoulis, E. (2007). Comparative efficiency analysis of Portuguese bank branches. European Journal of Operational Research, 177(2), 1275-1288.

doi:10.1016/j.ejor.2006.01.007

Rangan, N., Grabowski, R., Aly, H. Y., \& Pasurka, C. (1988). The technical efficiency of US banks. 
Economics Letters, 28(2), 169-175. doi:10.1016/0165-1765(88)90109-7

Rotolo, D., Rafols, I., Hopkins, M., \& Leydesdorff, L. (2013). Scientometric intelligence on emerging technologies: Scientometrics overlay mapping. Journal of the Association for Information Science and Technology. Digital Libraries.

Sathye, M. (2001). X-efficiency in Australian banking: An empirical investigation. Journal of Banking E Finance, 25(3), 613-630. doi:http://dx.doi.org/10.1016/S0378-4266(00)00156-4

Seiford, L. M., \& Thrall, R. M. (1990). Recent developments in DEA. Journal of Econometrics, 46(1-2), 7-38. doi:10.1016/0304-4076(90)90045-U

Seiford L. 1996. A bibliography for Data Envelopment Analysis (1978-1996). Annals of Operations Research, 73, 393-438

Sharpe, W. F. (1966). Mutual fund performance. The Journal of Business, 39(1), 119-138. http://www.jstor.org/stable/2351741

Sherman, H. D., \& Gold, F. (1985). Bank branch operating efficiency: Evaluation with Data Envelopment Analysis. Journal of Banking \& Finance, 9(2), 297-315. doi:http://dx.doi.org/10.1016/0378-4266(85)90025-1

Siriopoulos, C., \& Tziogkidis, P. (2010). How do Greek banking institutions react after significant events?-A DEA approach. Omega, 38(5), 294-308.

Soteriou, A., \& Zenios, S. A. (1999). Operations, quality, and profitability in the provision of banking services. Management Science, 45(9), 1221-1238. doi:10.1287/mnsc.45.9.1221

Sturm, J.-E., \& Williams, B. (2004). Foreign bank entry, deregulation and bank efficiency: Lessons from the Australian experience. Journal of Banking \& Finance, 28(7), 1775-1799. doi:http://dx.doi.org/10.1016/j.jbankfin.2003.06.005

Thanassoulis, E. (1999). Data envelopment analysis and its use in banking. Interfaces, 29(3), 1-13. http://pubsonline.informs.org/doi/abs/10.1287/inte.29.3.1?journalCode=inte. Accessed 3 June 2015

Vassiloglou, M., \& Giokas, D. (1990). A study of the relative efficiency of bank branches: An application of Data Envelopment Analysis. Journal of the Operational Research Society, 41(7), 591-597. doi:10.1057/jors.1990.83

Wanke, P., \& Barros, C. P. (2016). Efficiency drivers in Brazilian insurance: A two-stage DEA meta frontier-data mining approach. Economic Modelling, 53, 8-22. doi:10.1016/j.econmod.2015.11.005

Whitley, E. a., \& Galliers, R. D. (2007). An alternative perspective on citation classics: Evidence from the first 10 years of the European Conference on Information Systems. Information $\mathcal{E}$ Management, 44(5), 441-455.

Worthington, A. C. (2004). Frontier efficiency measurement in health care: a review of empirical techniques and selected applications. Medical care research and review :MCRR, 61(2), 135-170. doi:10.1177/1077558704263796

Xie, X. Y., Lu, W. L., Reising, J., \& Stohs, M. H. (2011). Demutualisation, control and efficiency in the U.S. life insurance industry. Geneva papers on Risk and Insurance-Issues and Practice.

Yang, X., \& Morita, H. (2013). Efficiency improvement from multiple perspectives: An application to Japanese banking industry. Omega, 41(3), 501-509. doi:10.1016/j.omega.2012.06.007

Zhou, P., Ang, B. W., \& Poh, K. L. (2008). A survey of data envelopment analysis in energy and 
environmental studies. European Journal of Operational Research, 189(1), 1-18.

doi:10.1016/j.ejor.2007.04.042 